\title{
Roles of Calcium-Stimulated Adenylyl Cyclase and Calmodulin-Dependent Protein Kinase IV in the Regulation of FMRP by Group I Metabotropic Glutamate Receptors
}

\author{
Hansen Wang, Long-Jun Wu, Fuxing Zhang, and Min Zhuo \\ Department of Physiology, Faculty of Medicine, University of Toronto, Toronto, Ontario, Canada M5S 1A8
}

\begin{abstract}
The fragile $\mathrm{X}$ syndrome is caused by the lack of fragile $\mathrm{X}$ mental retardation protein (FMRP) attributable to silencing of the FMR1 gene. The metabotropic glutamate receptors (mGluRs) in the CNS contribute to different brain functions, including learning/memory, mental disorders, drug addiction, and persistent pain. Most of the previous studies have been focused on downstream targets of FMRP in hippocampal neurons, and fewer studies have been reported for the second-messenger signaling pathways between group I mGluRs and FMRP. Furthermore, no molecular study has been performed in the anterior cingulate cortex (ACC), a key region involved in high brain cognitive and executive functions. In this study, we demonstrate that activation of group I mGluR upregulated FMRP in ACC neurons of adult mice through the $\mathrm{Ca}^{2+}$-dependent signaling pathways. Using genetic approaches, we found that $\mathrm{Ca}^{2+} /$ calmodulin-stimulated $^{2}$ adenylyl cyclase 1 (AC1) and calcium/calmodulin-dependent kinase IV (CaMKIV) contribute to the upregulation of FMRP induced by stimulating group I mGluRs. The upregulation of FMRP occurs at the transcriptional level. The cAMP-dependent protein kinase is activated by stimulating group I mGluRs through $\mathrm{AC} 1$ in $\mathrm{ACC}$ neurons. Both $\mathrm{AC} 1$ and CaMKIV contribute to the regulation of FMRP by group I mGluRs probably through cAMP response element-binding protein activation. Our study has provided the first evidence for a molecular link between group I mGluRs and FMRP in ACC neurons and may help us to understand the pathogenesis of fragile X syndrome.
\end{abstract}

Key words: adenylyl cyclase 1; CaMKIV; CREB; FMRP; group I mGluRs; cingulate cortex

\section{Introduction}

Fragile X syndrome, the most common inherited form of human mental retardation and an identified cause for autism, is caused by mutations of the FMR1 gene that encodes the fragile X mental retardation protein (FMRP) (Feng et al., 1995; Jin and Warren, 2003; Belmonte and Bourgeron, 2006; Huber, 2007). FMRP, an mRNA binding protein, is believed to play an important role in activitydependent synaptic plasticity through biochemical regulation of local protein synthesis at synapses (Greenough et al., 2001; Huber et al., 2002; Bagni and Greenough, 2005). The abnormal functions of group I metabotropic glutamate receptor (mGluR)-dependent synaptic plasticity have been observed in hippocampus of Fmrl knockout (KO) mice (Huber et al., 2002; Bear et al., 2004; Hou et al., 2006; Nakamoto et al., 2007). The function of group I mGluR activation require the translation of preexisting mRNA near active synapses. FMRP normally functions as a repressor of translation of specific mRNAs (Greenough et al., 2001; Bear et al., 2004; Bagni and

\footnotetext{
Received Nov. 15, 2007; revised March 19, 2008; accepted March 21, 2008.

This work was supported by grants from the ELLB-Canadian Institutes of Health Research (CIHR) Michael Smith Chair in Neurosciences and Mental Health, Canada Research Chair, and NeuroCanada and CIHR Operating Grants CIHR66975 and CIHR84256. H.W. and L.-J.W. were supported by postdoctoral fellowships from The Fragile X Research Foundation of Canada. We thank Dr. Louis J. Muglia for providing the AC1 and AC8 KO mice and Dr. W. T. Greenough for the generous gift of $F m r 1$ WT and KO breeding pairs.

Correspondence should be addressed to Dr. Min Zhuo, Department of Physiology, Faculty of Medicine, University of Toronto, 1 King's College Circle, Toronto, Ontario, Canada M5S 1A8. E-mail: min.zhuo@utoronto.ca.

DOI:10.1523/JNEUROSCI.0646-08.2008

Copyright $\odot 2008$ Society for Neuroscience $\quad 0270-6474 / 08 / 284385-13 \$ 15.00 / 0$
}

Greenough, 2005; Grossman et al., 2006). It is possible that the protein synthesis-dependent functions of mGluR activation are exaggerated because of the lack of FMRP in fragile $\mathrm{X}$ syndrome (Bear et al., 2004; Hou et al., 2006).

Recent studies from animal models reveal that the anterior cingulate cortex (ACC) plays an important role in cognitive learning, fear memory, and persistent pain (Frankland et al., 2001, 2004; Han et al., 2003; Zhao et al., 2005b; Zhuo, 2006, 2008). Trace fear memory is sensitive to attention-distracting stimulation and requires the activity of ACC (Han et al., 2003). Attention control difficulties have been observed in fragile $\mathrm{X} \mathrm{pa-}$ tients (Scerif et al., 2007). Interestingly, trace fear memory is impaired in Fmrl KO mice, accompanied by alterations in synaptic plasticity in ACC (Zhao et al., 2005a; Hayashi et al., 2007). These findings suggest that the dysfunction of ACC attributable to lack of FMRP may be responsible for certain types of mental disorders in fragile X syndrome. Electrophysiological and behavioral studies in animals found that the mGluRs in ACC may contribute to activity-dependent synaptic plasticity and behavioral fear memory (Wei et al., 1999; Tang et al., 2005). It is conceivable that mGluRs may regulate the expression of FMRP in ACC neurons, and the loss of this signaling pathway may contribute to the pathogenesis of fragile $\mathrm{X}$ syndrome. However, previous studies of the regulation of FMRP by mGluRs are mostly performed in hippocampus, and no study has been reported for the signaling pathway linking mGluRs and FMRP in ACC. 
In the present study, we have demonstrated that activation of group I mGluRs increased FMRP in neurons from adult mouse cingulate slices. Using gene $\mathrm{KO}$ mice lacking adenylyl cyclase 1 (AC1) or calcium/calmodulin-dependent kinase IV (CaMKIV), we found that both AC1 and CaMKIV contribute to the upregulation of FMRP by $(R S)$-3,5-dihydroxyphenylglycine (DHPG), an agonist of group I mGluRs. By measuring the activation of cAMP-dependent protein kinase (PKA) and cAMP response element-binding protein (CREB), we provide evidence that PKA is activated by stimulating group I mGluRs through AC1; DHPG application also activated CREB, and both $\mathrm{AC} 1$ and CaMKIV are involved in the activation of CREB. Because the CREB pathway is not affected in Fmrl KO mice, we propose that activation of group I mGluRs may upregulate FMRP through the $\mathrm{Ca}^{2+}$ stimulated CREB signaling pathway.

\section{Materials and Methods}

Animals. Adult male C57BL/6 mice were used in most of experiments. Mutant male mice lacking $A C 1, A C 8$, or $C a M K I V$ KO mice were derived as described previously and bred for several generations (F12-F16) on C57BL/6 background (Wei et al., 2002a,b, 2006). Wild-type (WT) mice from littermates of the mutant mice were also used as additional control mice. Fmr 1 WT and KO mice of the FVB.129P2-Fmr1tm1Cgr strain were generously provided by Dr. W. T. Greenough (University of Illinois at Urbana-Champaign, Urbana, IL), the mice were generated and maintained as reported previously (Weiler et al., 2004; Zhao et al., 2005a). All mice were housed under a 12 light/dark cycle with food and water provided ad libitum. All mouse protocols are in accordance with National Institutes of Health guidelines and approved by the Animal Care and Use Committee of University of Toronto.

Drugs and antibodies. DHPG, $(2 R, 4 R)-4$-aminopyrrolidine-2,4dicarboxylate $[(2 R, 4 R)$-APDC $], \quad(1 S, 3 R, 4 S)$-1-aminocyclopentane1,3,4-tricarboxylic acid (ACPT-I), 6 methoxy- $N$-(4-methoxyphenyl)-4quinazolinamine hydrochloride (MPMQ), 3-amino-6-chloro-5dimethylamino- $N$-2-pyridinylpyrazinec arboxamide hydrochloride (ACDPP), DL-AP-3, and KT5720 [(9R,10S,12S)-2,3,9,10,11,12hexahydro-10-hydroxy-9-methyl-1-oxo-9,12-epoxy- $1 H$-diindolo[1,2,3-fg:3', 2' $1^{\prime}$-kl] pyrrolo[3,4-i] [1,6] benzodiazocine-10-carboxylicacid hexyl ester] were purchased from Tocris Bioscience (Ellisville, $\mathrm{MO}$ ). Actinomycin D, cyclopiazonic acid (CPA), nifedipine (Nif), phosphatase inhibitor cocktail, and phosphatase inhibitor cocktail 1 and 2 were purchased from Sigma (St. Louis, MO). The anti-FMRP antibody, horseradish peroxidase-linked goat anti-mouse IgG, and goat anti-rabbit IgG for Western blot were purchased from Millipore Bioscience Research Reagents (Temecula, CA). The anti-CREB antibody and anti-phosphorylated-CREB (pCREB) antibody were purchased from Cell Signaling Technology (Danvers, MA). The antiactin antibody was from Sigma. The anti-CaMKIV antibody was from BD Biosciences (San Jose, CA).

Brain slice preparations. Mice were anesthetized with $2 \%$ halothane, and brain slices $(300 \mu \mathrm{m})$ containing ACC were cut at $4^{\circ} \mathrm{C}$ using a vibratome, in oxygenated artificial CSF (ACSF) containing the following (in mm): $124 \mathrm{NaCl}, 2 \mathrm{KCl}, 26 \mathrm{NaHCO}_{3}, 2 \mathrm{CaCl}_{2}, 2 \mathrm{MgSO}_{4}, 1 \mathrm{NaH}_{2} \mathrm{PO}_{4}$, and $10 \mathrm{D}$-glucose, $\mathrm{pH}$ 7.4. The slices were slowly brought to final temperature of $30^{\circ} \mathrm{C}$ in ACSF gassed with $95 \% \mathrm{O}_{2} / 5 \% \mathrm{CO}_{2}$ and incubated for at least $1 \mathrm{~h}$ before experiments. Slices then were exposed to different compounds of interest for the indicated times and snap frozen over dry ice. For biochemical experiments, the ACC regions were microdissected and sonicated in ice-cold homogenization buffer containing phosphatase and protease inhibitors. For electrophysiology and calcium imaging, brain slices were transferred to a submerged recovery chamber with oxygenated ACSF at room temperature.

Immunohistochemistry. The ACC sections from the control and DHPG treatment group were processed simultaneously to allow the same condition and time for DAB staining. Cryostat-cut brain sections $(30 \mu \mathrm{m})$ were processed with mouse anti-FMRP (1:500) and rabbit anti-pCREB antibody (1:500). The avidin-biotin protocol was used as described pre- viously (Wei et al., 2002b). Images were collected on an Olympus (Tokyo, Japan) BX 60 microscope and analyzed using NIH Image J software (Scion, Frederick, MD).

Western blot analysis. Western blot was conducted as described previously (Wang et al., 2007). The brain tissues were dissected and homogenized in lysis buffer containing $10 \mathrm{~mm}$ Tris- $\mathrm{HCl}, \mathrm{pH}$ 7.4, 2 mм EDTA, 1\% SDS, $1 \times$ protease inhibitor cocktail, and $1 \times$ phosphatase inhibitor cocktail 1 and 2. Protein was quantified by Bradford assay. Electrophoresis of equal amounts of total protein was performed on SDS-polyacrylamide gels. Separated proteins were transferred to polyvinylidene fluoride membranes at $4^{\circ} \mathrm{C}$ for analysis. Membranes were probed with 1:3000 dilution of anti-FMRP, 1:1000 dilution of anti-pCREB (Ser133) and antiCREB, or 1:2000 dilution of anti-CaMKIV antibodies. The membranes were incubated in the appropriate horseradish peroxidase-coupled secondary antibody diluted 1:3000 for $1 \mathrm{~h}$ followed by enhanced chemiluminescence detection of the proteins with Western lightning chemiluminescence reagent plus according to the instructions of the manufacturer. To verify equal loading, membranes were also probed with 1:3000 dilution of anti-actin antibody. The density of immunoblots was measured using NIH ImageJ program.

Reverse transcription-PCR. The total RNA from the ACC was isolated using RNAspin Mini kit (GE Healthcare, Little Chalfont, UK). Reverse transcription (RT)-PCR was performed using SuperScript One-Step RTPCR System with Platinum TaqDNA Polymerase. A $25 \mu$ l PCR containing $0.5 \mu$ g of total RNA, $5 \mu$ l of $5 \times$ RT-PCR buffer, $400 \mu \mathrm{M}$ dNTP, $0.5 \mu \mathrm{M}$ of each primer, and $1 \mu \mathrm{l}$ of RT-PCR enzyme. PCR conditions were adjusted to be in a linear range of amplification. The PCR cycles consisted of initial incubation at $94^{\circ} \mathrm{C}$ for $1 \mathrm{~min}$; denaturation at $94^{\circ} \mathrm{C}$ for $45 \mathrm{~s}$; annealing at $56^{\circ} \mathrm{C}$ for $45 \mathrm{~s}$; and extension at $72^{\circ} \mathrm{C}$ for $1 \mathrm{~min}$, for 30 cycles, and final extension at $72^{\circ} \mathrm{C}$ for $10 \mathrm{~min}$. The primers for Fmrl used in this experiment were as follows: sense, $5^{\prime}$-CCGAACAGATAATCGTCCACG3'; antisense, 5'-ACGCTGTCTGGCTTTTCC TTC-3'. Glyceraldehyde-3phosphate dehydrogenase (GAPDH) was amplified as an internal control by using the following primer sets: sense, 5-AACGACCCCTTCATTGAC-3'; antisense 5'-TCCACGACATACTCAGCAC-3'. RT-PCR products were electrophoresed on $1.5 \%$ agarose gels and visualized under UV light by ethidium bromide staining. The relative density of bands was analyzed by the NIH ImageJ program.

cAMP assay. After treatment with DHPG, the ACC tissues were harvested and lysed in $0.1 \mathrm{M} \mathrm{HCl}$. Direct cAMP measurements were performed using the direct cAMP enzyme immunoassay kit (Assay Designs, Ann Arbor, MI) according to the protocol of the manufacturer. Phosphodiesterase was inhibited by the addition of $1 \mathrm{~mm} 3$-isobutyl-1 methylxanthine (Sigma) in this process.

PKA activity assay. The PKA activity was measured using the PKA kinase activity kit (Assay Designs). The relative PKA activity in the samples was calculated according to the following formula: relative kinase activity $=[$ absorbance of samples - absorbance of blank $]$ /quantity of protein used in per assay.

Whole-cell patch-clamp recording. Brain slices were transferred to a recording chamber and perfused with oxygenated ACSF solution at 3-4 $\mathrm{ml} / \mathrm{min}$ at room temperature. Whole-cell patch-clamp recordings were made on the soma of ACC pyramidal neurons. Recording electrodes (2-3 $\mathrm{M} \Omega$ ) contained an $\mathrm{K}^{+}$-based internal solution composed of the following (in mM): $120 \mathrm{~K}$-gluconate, $5 \mathrm{NaCl}, 1 \mathrm{MgCl}_{2}, 0.5$ EGTA, $0.1 \mathrm{Na}_{3} \mathrm{GTP}$, 10 HEPES, and 0.4 Oregon green BAPTA-1 (OGB-1), pH 7.2 (280-300 $\mathrm{mOsm})$. Unless otherwise stated, the membrane potential was held at $-60 \mathrm{mV}$ for neurons throughout all experiments. To record DHPGinduced current, tetrodotoxin ( $1 \mathrm{~mm}$ ) was added in the ACSF. Data were amplified and filtered at $2 \mathrm{kHz}$ by a patch-clamp amplifier (Axopatch 200B), digitalized (DIGIDATA 1322A), stored, and analyzed by pClamp (Molecular Devices, Union City, CA).

Calcium imaging. OGB-1 (0.4 mM; Invitrogen, Carlsbad, CA) was dialyzed into ACC neurons by whole-cell patch pipette. After entering whole-cell mode, the cells were maintained for $>10$ min to allow for filling with OGB-1 before image acquisition. Fluorescent signals were imaged by confocal microscope (Fluoview FV 1000; Olympus). The laser with a wavelength of $488 \mathrm{~nm}$ was used for excitation, and fluorescence was recorded through a bandpass filter $(500-550 \mathrm{~nm})$. The 
A FMRP immunostaining

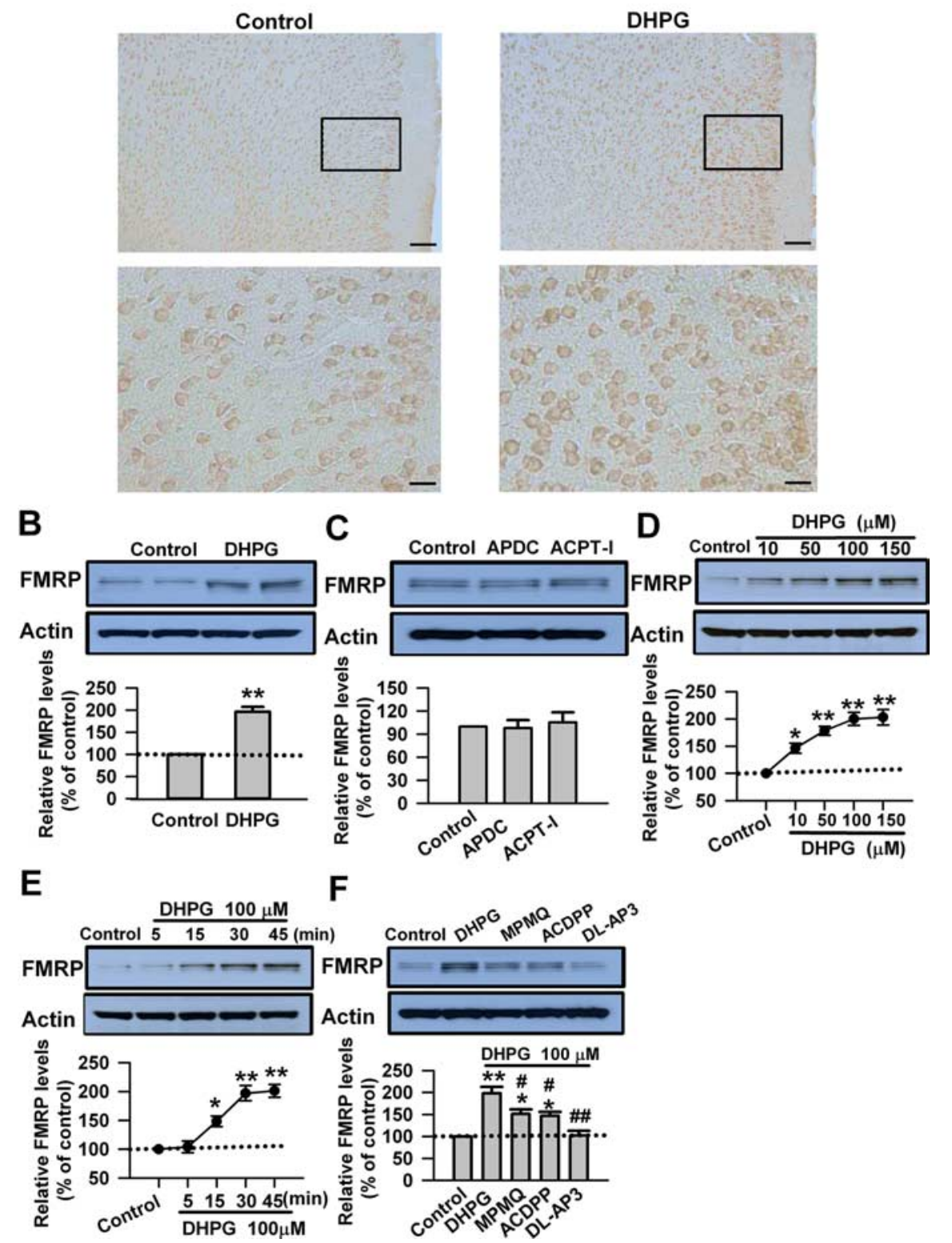

Figure 1. Activation of group I mGluRs upregulates FMRP in ACC neurons. A, Immunohistochemistry of FMRP in ACC. Compared with the control (left), the increase of the immunoreactivity of FMRP by DHPG (100 $\mu \mathrm{m}, 30 \mathrm{~min}$; right) could be found in neurons from layers II-VI in ACC. A high-magnification image of the selected part showing the staining in layers II and III is provided at the bottom. Scale bars: top, $100 \mu \mathrm{m}$; bottom, $25 \mu \mathrm{m}$. B, Application of the group I mGluR agonist DHPG (100 $\mu \mathrm{M})$ for $30 \mathrm{~min}$ increased the levels of FMRP in $A C C$, as measured by Western blot. $C$, Application of the group II mGluR agonist $(2 R, 4 R)-A P D C(10$ $\mu \mathrm{M})$ or group III mGluR agonist ACPT-I (100 $\mu \mathrm{m})$ for $30 \mathrm{~min}$ did not affect the levels of FMRP in ACC slices. $\boldsymbol{D}$, The levels of FMRP were increased by DHPG $(10-150 \mu \mathrm{m})$ in a dose-dependent manner. The highest level of FMRP was seen at $100 \mu \mathrm{m}$; DHPG at higher concentration (150 $\mu \mathrm{M})$ did not cause additional increase of FMRP. E, DHPG $(100 \mu \mathrm{M})$ increased FMRP in a time-dependent manner, the increase was observed at $15 \mathrm{~min}$, and the highest increase was reached at $30 \mathrm{~min} . \boldsymbol{F}$, The increase of FMRP caused by DHPG was partially blocked by the selective mGluR1 antagonist MPMQ $(10 \mu \mathrm{M})$ or a specific $\mathrm{mGluR5}$ antagonist of ACDPP $(10 \mu \mathrm{M})$; the presence of the group I mGluR antagonist DL-AP-3 $(100 \mu \mathrm{M})$ completely blocked the increase of FMRP caused by DHPG in ACC slices. The antagonists were applied to slices $20 \mathrm{~min}$ before and during the DHPG treatment. Representative Western blot (top) and quantification data (bottom) of FMRP levels are shown for corresponding treatments from $\boldsymbol{B}-\boldsymbol{F}$. Data were normalized by the control values. ${ }^{*} p<0.05,{ }^{* *} p<0.01$ compared with control; ${ }^{*} p<0.05,{ }^{\# \#} p<0.01$ compared with DHPG treatment; $n=3$ mice for each group in $\boldsymbol{A} ; n=6$ mice for each group in $\boldsymbol{B} ; n=4$ mice for each group in $\mathbf{C}-\boldsymbol{F}$.

images were acquired using $40 \times 0.8$ numeric aperture water-immersion objectives every $5 \mathrm{~s}$ after a $188 \mathrm{~ms}$ exposure to $488 \mathrm{~nm}$ light. XYT image galleries were collected, and average fluorescence intensity in the soma was measured for the quantification. The intensity was expressed as $F / F_{0}$, where $F_{0}$ is the fluorescence intensity before DHPG treatment.
Data analysis. Statistical comparisons were made using the paired $t$ test or one-way or two-way ANOVA (Student-Newman-Keuls test was used for post hoc comparison). All data were presented as the mean \pm SEM. In all cases, $p<0.05$ is considered statistically significant.

\section{Results}

Activation of group I mGluRs upregulates FMRP in the ACC neurons Previous studies of the regulation of FMRP by mGluRs have mainly been performed in cultured cortical neurons and hippocampal slices (Weiler et al., 1997; Todd et al., 2003; Hou et al., 2006). In this study, we investigated the effects of mGluR activation on the expression of FMRP in ACC slices from adult mice. By immunohistochemistry, we found FMRP was well expressed in the ACC at the basal condition. Application of the group I mGluR agonist DHPG $(100 \mu \mathrm{M})$ to ACC slices for 30 min caused a widespread increase of FMRP immunoreactivity from layers II-VI in the ACC (Fig. 1A). The increase of FMRP levels by DHPG in the ACC was also measured by Western blot (196 \pm $11 \%$ of the control levels; $p<0.01$ compared with control; $n=6$ ) (Fig. $1 B$ ). In contrast, bath application of the group II mGluR agonist $(2 R, 4 R)$-APDC $(10 \mu \mathrm{M})$ or group III mGluR agonist ACPT-I (100 $\mu \mathrm{M}$ ) for $30 \mathrm{~min}$ did not cause changes in FMRP levels in the ACC slices $(p>0.05$ compared with control; $n=4$ ) (Fig. 1C). These data indicate that activation of group I mGluRs upregulates FMRP in ACC neurons.

The effect of DHPG on FMRP expression was further characterized in ACC slices. We found that the FMRP levels were increased by DHPG $(10-150 \mu \mathrm{M})$ in a dose-dependent manner. The highest level of FMRP was observed at $100 \mu \mathrm{M}$, whereas DHPG at $150 \mu \mathrm{M}$ did not cause additional increase in FMRP level ( $p<0.01$ compared with control; $n=4$ ) (Fig. $1 D)$. In addition, DHPG $(100 \mu \mathrm{M})$ increased FMRP expression in a time-dependent manner, the increase could be observed at $15 \mathrm{~min}$, the highest level was reached after $30 \mathrm{~min}$ ( $p<0.01$ compared with control; $n=4)$ (Fig. $1 E$ ).

The group I mGluRs consist of two subtypes, mGluR1 and mGluR5 (Coutinho and Knopfel, 2002; Thuault et al., 2002; Moult et al., 2006). To identify which group I mGluR subtype(s) was responsible for the increase of FMRP caused by DHPG, we applied DHPG $(100 \mu \mathrm{M})$ to ACC slices in the presence of either the selective mGluR1 antagonist MPMQ $(10 \mu \mathrm{M})$ or a specific mGluR5 antagonist of ACDPP $(10 \mu \mathrm{M})$. We found that the increase of 
FMRP caused by DHPG was only partially blocked by MPMQ or ACDPP $(p<0.05$ compared with control or compared with DHPG treatment; $n=4$ ) (Fig. $1 F$ ). However, the presence of group I mGluR antagonist DL-AP-3 (100 $\mu \mathrm{M})$ completely blocked the increase of FMRP caused by DHPG in ACC slices $(p<0.01$ compared with DHPG treatment; $n=4)$ (Fig. $1 F)$. These data confirm that group I mGluRs, including mGluR1 and mGluR5, regulate FMRP in ACC neurons.

Calcium is critical for the regulation of FMRP by group I mGluRs

During group I mGluR activation, $\mathrm{Ca}^{2+}$ could be released from $\mathrm{IP}_{3}$-sensitive intracellular stores and acts as a second messenger (Rae et al., 2000; Fitzjohn et al., 2001; Coutinho and Knopfel, 2002; Heinke and Sandkuhler, 2007). The sarco/endoplasmic reticulum $\mathrm{Ca}^{2+} / \mathrm{AT}$ Pase (SERCA) pump inhibitor cyclopiazonic acid depletes intracellular stores of $\mathrm{Ca}^{2+}$ by blocking $\mathrm{Ca}^{2+}$ reuptake into the stores (Rae et al., 2000; Heinke and Sandkuhler, 2007). To examine the role of $\mathrm{Ca}^{2+}$ release from intracellular stores in the upregulation of FMRP by DHPG, CPA $(30 \mu \mathrm{M})$ was applied to ACC slices 20 min before and during the DHPG (100 $\mu \mathrm{M}, 30 \mathrm{~min}$ ) treatment. We found that the upregulation of FMRP by DHPG was partially blocked by cyclopiazonic acid ( $193 \pm 7$ and $132 \pm 9 \%$ of the control levels for DHPG and CPA treatment, respectively; $p<0.05$ compared with DHPG treatment; $n=6$ ) (Fig. $2 A$ ).

Activation of group I mGluRs can facilitate L-type voltage-dependent $\mathrm{Ca}^{2+}$ channels (L-VDCCs) in different cell types (Chavis et al., 1995, 1996; Heinke and Sandkuhler, 2005). DHPG treatment may induce $\mathrm{Ca}^{2+}$ influx through L-VDCCs in striatal neurons (Mao and Wang, 2003).

Here, we found that application of L-VDCC blocker Nif $(25 \mu \mathrm{M})$ $20 \mathrm{~min}$ before and during the DHPG treatment also partially blocked the increase of FMRP caused by DHPG (198 \pm 12 and $146 \pm 11 \%$ of the control levels for DHPG and nifedipine treatment, respectively; $p<0.05$ compared with DHPG treatment; $n=6$ ) (Fig. $2 B$ ). In addition, coapplication of cyclopiazonic acid with nifedipine almost completely blocked the upregulation of FMRP by DHPG treatment $(190 \pm 1 \%$ and $106 \pm 11 \%$ of the control levels for DHPG and CPA plus nifedipine treatment, respectively; $p<0.01$ compared with DHPG treatment; $n=6$ ) (Fig. 2C). In contrast, cyclopiazonic acid, nifedipine, or coapplication of cyclopiazonic acid and nifedipine did not affect the basal levels of FMRP in ACC slices $(p>0.05$ compared with control; $n=4$ ) (Fig. $2 D$ ). These data indicate that both $\mathrm{Ca}^{2+}$ release from intracellular stores and $\mathrm{Ca}^{2+}$ influx through L-VDCCs are required for the regulation of FMRP by group I mGluRs in ACC neurons.

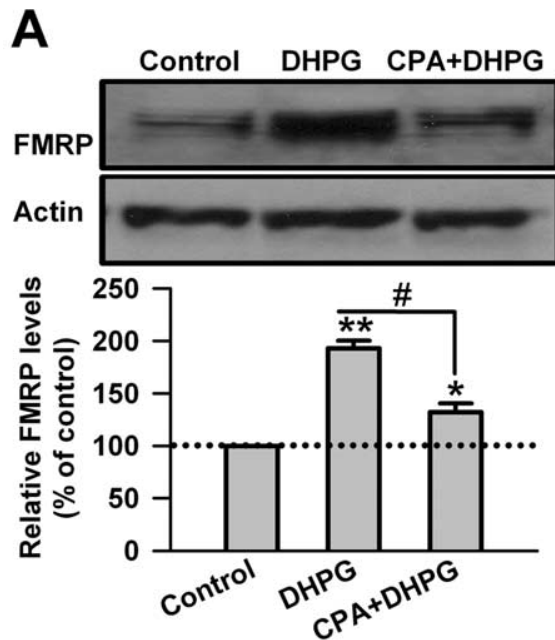

B
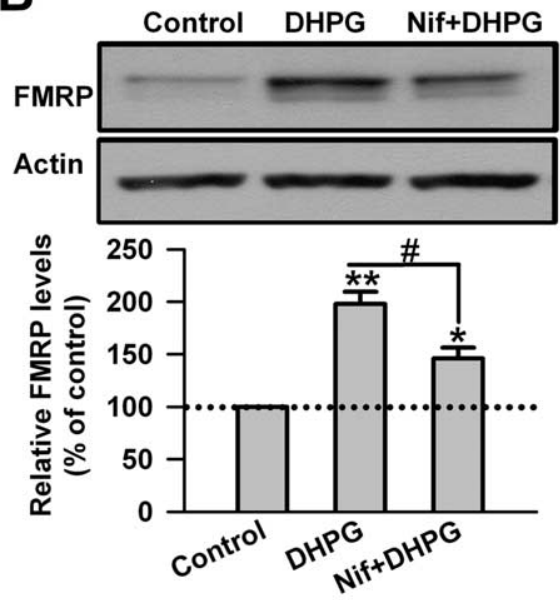

D
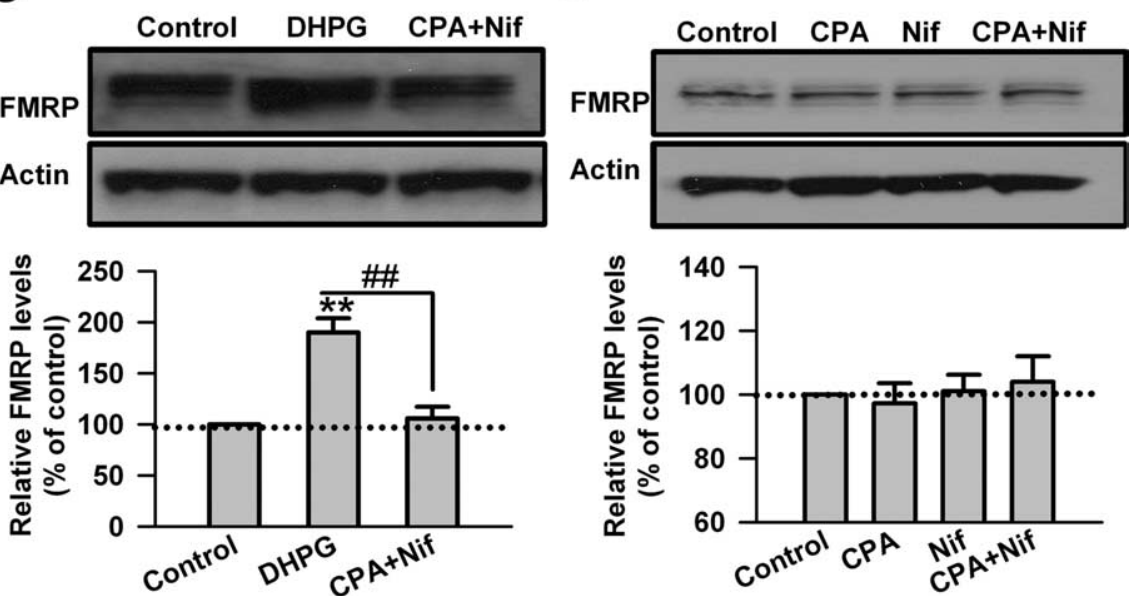

Figure 2. Calcium mediates the regulation of FMRP by group I mGluRs in ACC neurons. $A$, The SERCA pump inhibitor CPA (50 $\mu \mathrm{M})$ partially blocked the upregulation of FMRP by DHPG (100 $\mu \mathrm{M}, 30 \mathrm{~min})$. Cyclopiazonic acid was applied to slices 20 min before and during DHPG treatment. $\boldsymbol{B}$, L-type $\mathrm{Ca}^{2+}$ channels blocker Nif $(25 \mu \mathrm{M})$ partially blocked the increase of FMRP caused by DHPG treatment. Nifedipine was applied to slices 20 min before and during DHPG treatment. C, Coapplication of cyclopiazonic acid with to slices 20 min before and during DHPG treatment. D, Application of cyclopiazonic acid (50 $\mu \mathrm{M})$, nifedipine (25 $\mu \mathrm{M})$, or coapplication of cyclopiazonic acid with nifedipine for $30 \mathrm{~min}$ did not affect the basal levels of FMRP in ACC slices. Representative Western (bottom) of FMRP are shown for the corresponding treatments. Data were normalized by the control values. ${ }^{*} p<0.05,{ }^{* *} p<0.01$ compared with control; ${ }^{\#} p<0.05,{ }^{\# \#} p<0.01$ compared with DHPG treatment; $n=6$ mice for each group in $\boldsymbol{A}-\boldsymbol{C} ; n=4$ mice for each group in $\boldsymbol{D}$.

\section{AC1 contributes to the upregulation of FMRP in the ACC neurons}

The cAMP signaling pathway contributes to the activitydependent synaptic plasticity in ACC neurons (Wei et al., 2002b, 2006; Liauw et al., 2005; Zhuo, 2008). The group I mGluRs have been shown to potentiate cAMP accumulation in cultured striatal neurons, striatum, and cerebral cortex (Cartmell et al., 1997, 1998; Schaffhauser et al., 1997). Among the cAMP signaling pathway, AC1 and AC8 are the two major $\mathrm{Ca}^{2+} /$ calmodulin-stimulated AC isoforms (Cooper et al., 1998; Sunahara and Taussig, 2002; Wang and Storm, 2003; Cooper and Crossthwaite, 2006). No study has been reported for the involvement of AC1 and AC8 in the mGluR signaling pathway. Here we first used the AC1\&8 double KO (DKO) mice to explore the role of $\mathrm{Ca}^{2+} /$ calmodulin-stimulated ACs in the regulation of FMRP by group I mGluRs. We found that, although the basal FMRP levels were unaltered in ACC of $A C 1 \& 8$ DKO mice ( $p>0.05$ compared with WT mice; $n=4$ ) 
A
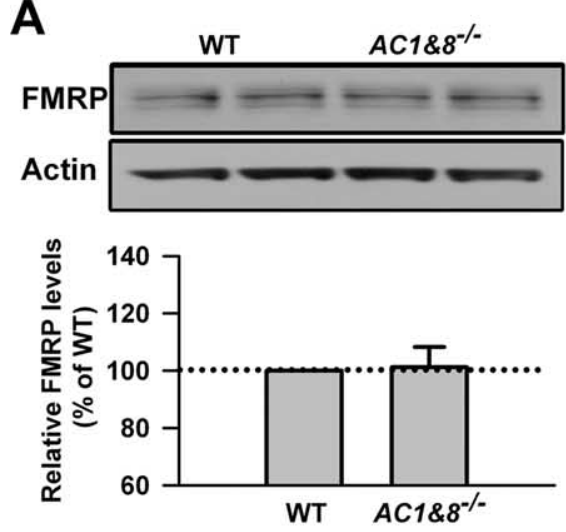

C
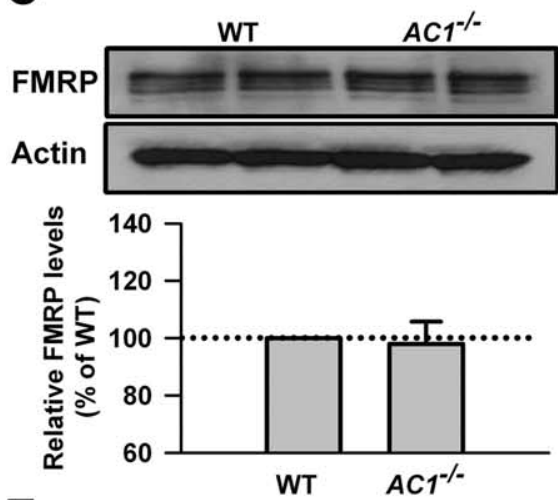

E
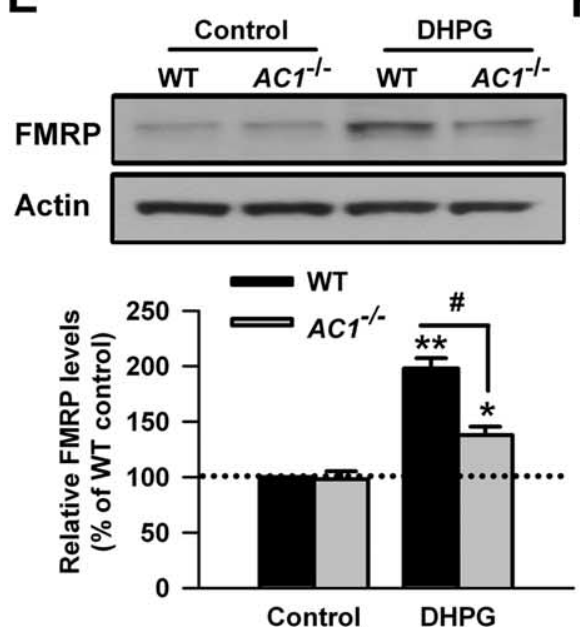

B

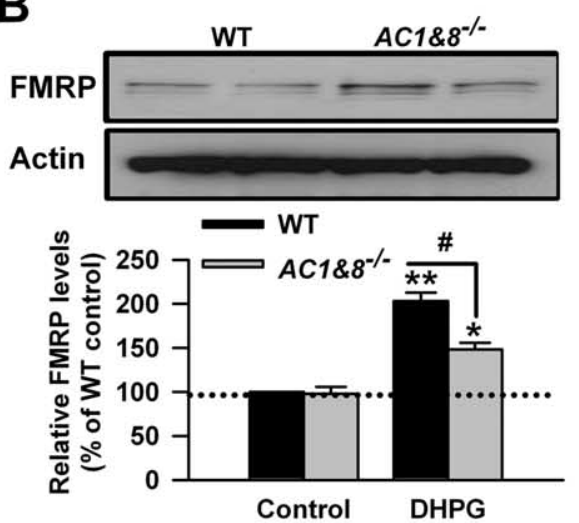

D

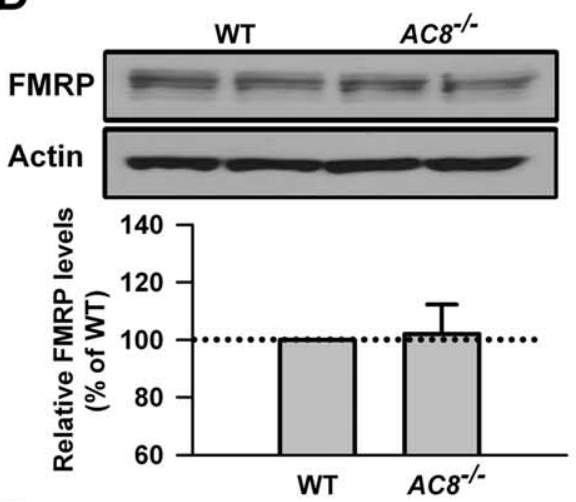

$\mathbf{F}$
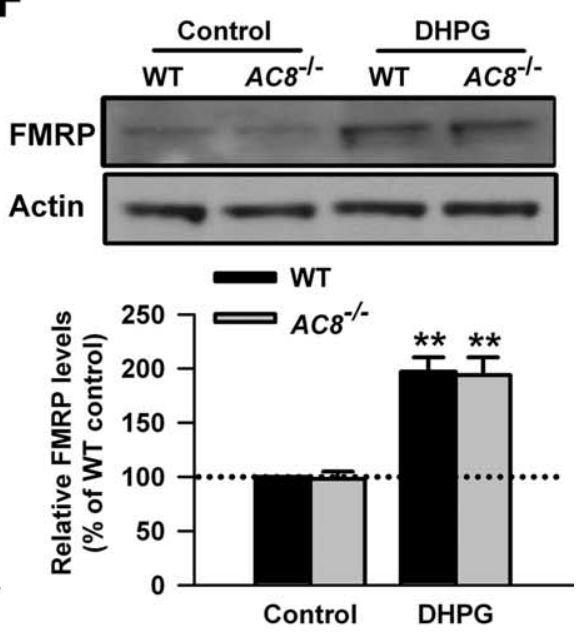

Figure 3. Upregulation of FMRP was partially blocked in ACC from mice lacking AC1. $A$, There was no difference in the basal levels of FMRP in ACC slices between WT and AC1\&8 DKO mice, as shown by Western blot. $\boldsymbol{B}$, The increase of FMRP in ACC slices treated by DHPG (100 $\mu \mathrm{m}, 30 \mathrm{~min})$ was partially blocked in $A C 1 \& 8 \mathrm{DKO}$ mice compared with WT mice. C, D, There was no difference in the basal levels of FMRP in ACC slices between WT and $A C 1 \mathrm{KO}(\boldsymbol{C})$ or $A C 8 \mathrm{KO}(\boldsymbol{D})$ mice, as shown by Western blot. $\boldsymbol{E}$, The increase of FMRP in ACC slices from AC1 KO mice was attenuated compared with WT mice. The slices were treated with DHPG $(100 \mu \mathrm{m})$ for $30 \mathrm{~min} . \boldsymbol{F}$, The increase of FMRP attributable to DHPG treatment (100 $\mu \mathrm{m}, 30 \mathrm{~min})$ in ACC slices from AC8 KO mice was not different from that in WT mice. Representative Western blot (top) and quantification data (bottom) of FMRP are shown for the corresponding treatments. Data were normalized by the WT control values. ${ }^{*} p<0.05,{ }^{* *} p<0.01$ compared with control; ${ }^{*} p<0.05$ compared with WT; $n=4$ mice for each group in $\boldsymbol{A}$ and $\boldsymbol{B} ; n=6$ mice for each group in $\boldsymbol{C}-\boldsymbol{F}$.

(Fig. 3A), the increase of FMRP caused by DHPG (100 $\mu \mathrm{M}, 30 \mathrm{~min}$ ) was partially blocked in $A C 1 \ll 8 \mathrm{DKO}$ mice compared with WT mice $(p<0.05$ compared with WT mice; $n=4)$ (Fig. 3B). These findings indicate that $\mathrm{Ca}^{2+} / \mathrm{calmodulin}$-stimulated ACs are involved in the regulation of FMRP by group I mGluRs in ACC neurons.

To address the specific roles of $\mathrm{AC} 1$ and AC8 in the upregulation of FMRP by stimulating group I mGluRs, we tested the effect of DHPG (100 $\mu \mathrm{M}, 30 \mathrm{~min})$ in ACC slices from $A C 1 \mathrm{KO}$ or $A C 8 \mathrm{KO}$ mice, respectively. By Western blot, we found that there was no difference in the basal levels of FMRP in ACC slices between WT and $A C 1 \mathrm{KO}$ or $A C 8 \mathrm{KO}$ mice ( $p>0.05$ compared with WT mice; $n=$ 6) (Fig. 3C,D). After ACC slices were treated with DHPG for $30 \mathrm{~min}$, we found that the increase of FMRP in ACC slices from $A C 1 \mathrm{KO}$ mice was attenuated compared with WT mice $(198 \pm 10$ and $138 \pm 9 \%$ of the WT control levels for WT and $A C 1 \mathrm{KO}$ mice, respectively; $p<$ 0.05 compared with WT mice; $n=6$ ) (Fig. 3E). However, the increase of FMRP attributable to DHPG treatment was not changed in ACC slices from AC8 KO mice $(197 \pm 14$ and $194 \pm 17 \%$ of the WT control levels for WT and AC8 KO mice, respectively; $p>0.05$ compared with WT mice; $n=6$ ) (Fig. $3 F$ ). These results indicate that $\mathrm{ACl}$, but not $\mathrm{AC} 8$, contributes to the regulation of FMRP by group I mGluRs in ACC neurons.

CaMKIV acts downstream of group I mGluRs in the ACC neurons

CaMKIV is a key effector in neuronal $\mathrm{Ca}^{2+}$ signaling and functions as a transcriptional activator (Bito et al., 1997; Ho et al., 2000; Hook and Means, 2001). It is expressed in both nuclei and cytosol of neurons in several brain regions, including cortex, cerebellum, hippocampus, and amygdala (Means et al., 1991; Sun et al., 1995; Ho et al., 2000). CaMKIV has been implicated in many aspects of neuronal $\mathrm{Ca}^{2+}$ signaling, including gene expression in response to excitatory neurotransmission (Ho et al., 2000; Hook and Means, 2001; Wei et al., 2002a). To explore the possible role of CaMKIV in the upregulation of FMRP by stimulating group I mGluRs, we tested the effect of DHPG $(100 \mu \mathrm{M}, 30$ min) treatment in ACC slices from CaMKIV KO mice. We found that there was no difference in the basal levels of FMRP in ACC slices between WT and CaMKIV KO mice ( $p>0.05$ compared with WT mice; $n=4$ ) (Fig. $4 A$ ). However, after the treatment with DHPG for $30 \mathrm{~min}$, we found that the increase of FMRP was partially blocked in ACC slices from CaMKIV KO mice compared with WT mice (202 \pm 10 and $139 \pm 11 \%$ of the WT control levels for WT and CaMKIV KO mice, respectively; $p<0.05$ compared with WT mice; 
A
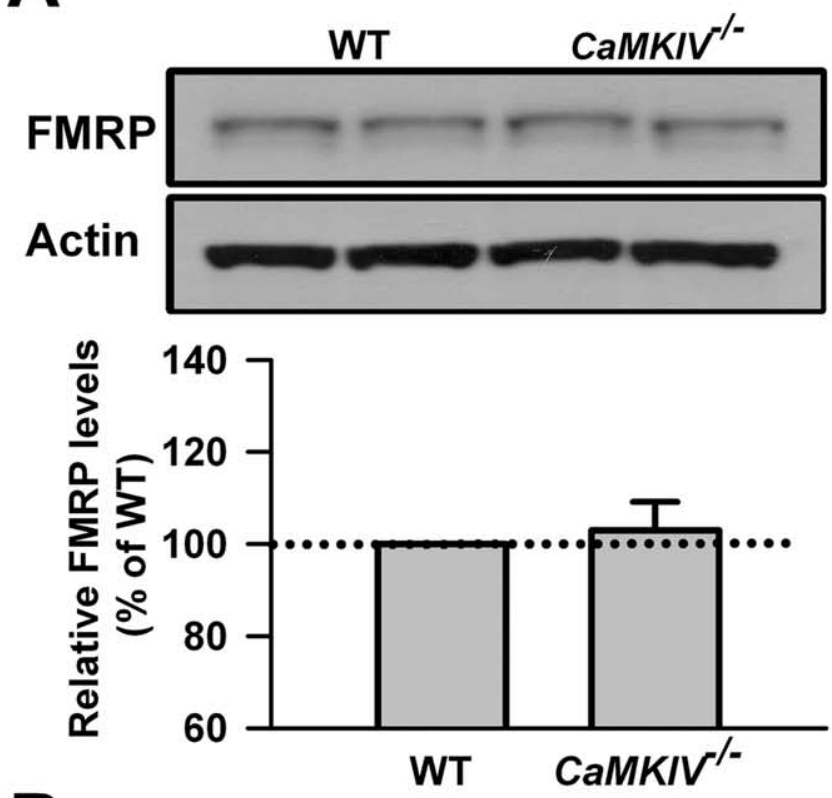

B
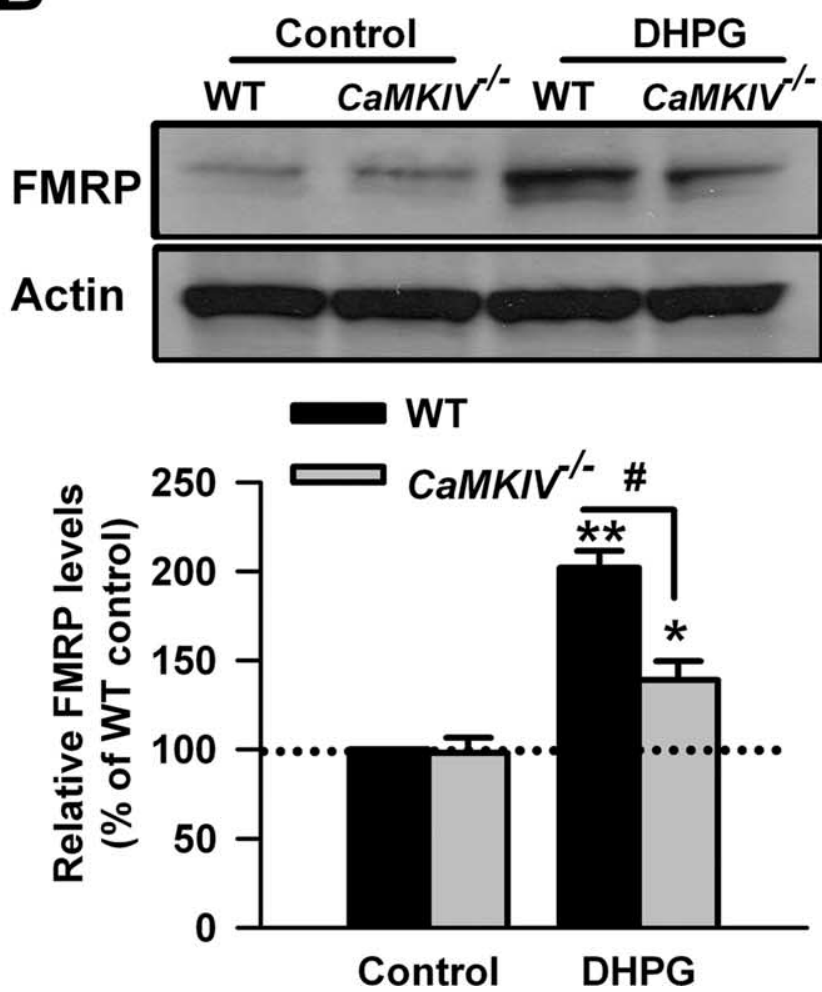

Figure 4. CaMKIV contributes to the upregulation of FMRP by group I mGluRs in ACC neurons. $\boldsymbol{A}$, There was no difference in the basal levels of FMRP in ACC slices between WT and CaMKIV KO mice. $\boldsymbol{B}$, The increase of FMRP after treatment with DHPG $(100 \mu \mathrm{M})$ for 30 min was attenuated in ACC slices from CaMKIV KO mice compared with WT mice. Representative Western blot (top) and quantification data (bottom) of FMRP are shown for the corresponding treatments. Data were normalized by WT control values. ${ }^{*} p<0.05,{ }^{* *} p<0.01$ compared with control; ${ }^{\#} p<0.05$ compared with WT; $n=4$ mice for each group.

$n=4)($ Fig. $4 B$ ). The data indicate that CaMKIV also acts as a downstream effector for group I mGluRs and contributes to the regulation of FMRP by group I mGluRs in ACC neurons.
Upregulation of FMRP by group I mGluRs occurs at the transcription level

One previous study has shown that stimulation of group I mGluRs with DHPG induces the increase of FMRP in a protein synthesis-dependent manner in hippocampus CA1 area (Hou et al., 2006). To examine whether the upregulation of FMRP by stimulating group I mGluR occurs at the transcriptional or translational level in ACC neurons, we tested the effect of inhibiting gene transcription in ACC neurons. We found that pretreatment with a transcription inhibitor, actinomycin D $(40 \mu \mathrm{M}), 20 \mathrm{~min}$ before and during DHPG application ( $100 \mu \mathrm{M}, 30 \mathrm{~min})$ abolished the DHPG-induced increase of FMRP in ACC slice (187 \pm 10 and $103 \pm 13 \%$ of the control levels for DHPG and actinomycin D treatment, respectively; $p<0.01$ compared with DHPG treatment; $n=6$ ) (Fig. 5A). The data indicate that the regulation of FMRP by I mGluRs occurs at the transcriptional level.

Can Fmrl mRNA be newly transcribed by stimulating I mGluRs in ACC neurons? To address this, we measured the levels of Fmr1 mRNA by RT-PCR. We found that DHPG (100 $\mu \mathrm{M}, 15$ min) treatment could increase the levels of Fmr1 mRNA in ACC slices $(220 \pm 12 \%$ of the control levels; $p<0.01$ compared with control; $n=4$ ) (Fig. 5B). There was no difference in the basal levels of Fmr1 mRNA in ACC between WT and AC1 or CaMKIV KO mice $(p>0.05 ; n=4)$ (Fig. $5 C, D)$. However, the increase of Fmr1 mRNA caused by DHPG treatment was partially blocked in ACC slices from $A C 1$ or CaMKIV KO mice ( $p<0.05$ compared with WT mice; $n=4$ ) (Fig. $5 C, D$ ). These data further confirm that group I mGluR activation upregulates FMRP at the transcriptional level, and AC1 and CaMKIV are required for the transcriptional regulation of FMRP by group I mGluRs in ACC neurons.

PKA is activated by stimulating group I mGluRs Once activated by $\mathrm{Ca}^{2+} /$ calmodulin, the $\mathrm{Ca}^{2+} /$ calmodulinstimulated ACs convert ATP to cAMP (Sunahara and Taussig, 2002; Cooper, 2003; Wang and Storm, 2003). To further characterize the roles of $\mathrm{Ca}^{2+}$ and $\mathrm{Ca}^{2+} /$ calmodulin-stimulated ACs in the regulation of FMRP by group I mGluRs, we measured the cAMP levels in ACC neurons. We found that application of DHPG (100 $\mu \mathrm{M}, 15 \mathrm{~min})$ increased the cAMP levels in ACC slice. We then tested the effects of SERCA pump inhibitor cyclopiazonic acid and L-VDCC blocker Nif $(25 \mu \mathrm{M})$. We found that application of CPA $(30 \mu \mathrm{M})$ or Nif $(25 \mu \mathrm{M})$ before and during DHPG treatment could partially block the increase of cAMP caused by DHPG ( $p<0.05$ compared with DHPG treatment; $n=4$ ) (Fig. 6A), and the increase of cAMP was completely blocked by coapplication of cyclopiazonic acid and nifedipine $(p<0.01$ compared with DHPG treatment; $n=4)$ (Fig. $6 A$ ). In contrast, cyclopiazonic acid, nifedipine, or coapplication of cyclopiazonic acid and nifedipine did not affect the basal levels of cAMP in ACC slices ( $p>0.05$ compared with control; $n=4$ ) (Fig. $6 B$ ). We next measured the cAMP levels in ACC slices from $A C 1 \mathrm{KO}$ or $A C 8 \mathrm{KO}$ mice. We found that the increase of cAMP caused by DHPG treatment was blocked in AC1 KO mice $(p<$ 0.05 compared with WT; $n=4$ ) (Fig. $6 C$ ) but not in $A C 8 \mathrm{KO}$ mice $(p>0.05$ compared with WT mice; $n=4)$ (Fig. 6C), whereas the basal levels of cAMP was not affected in ACC slices from AC1 KO or $A C 8 \mathrm{KO}$ mice ( $p>0.05$ compared with WT mice; $n=4$ ) (Fig. $6 C)$. These results demonstrate that both the intracellular calcium stores and external calcium influx through L-VDCC are required for the cAMP production after stimulation of group I mGluRs, and $\mathrm{AC} 1$ is specifically involved in this process.

The cellular effects of cAMP are mediated by PKA, a major 


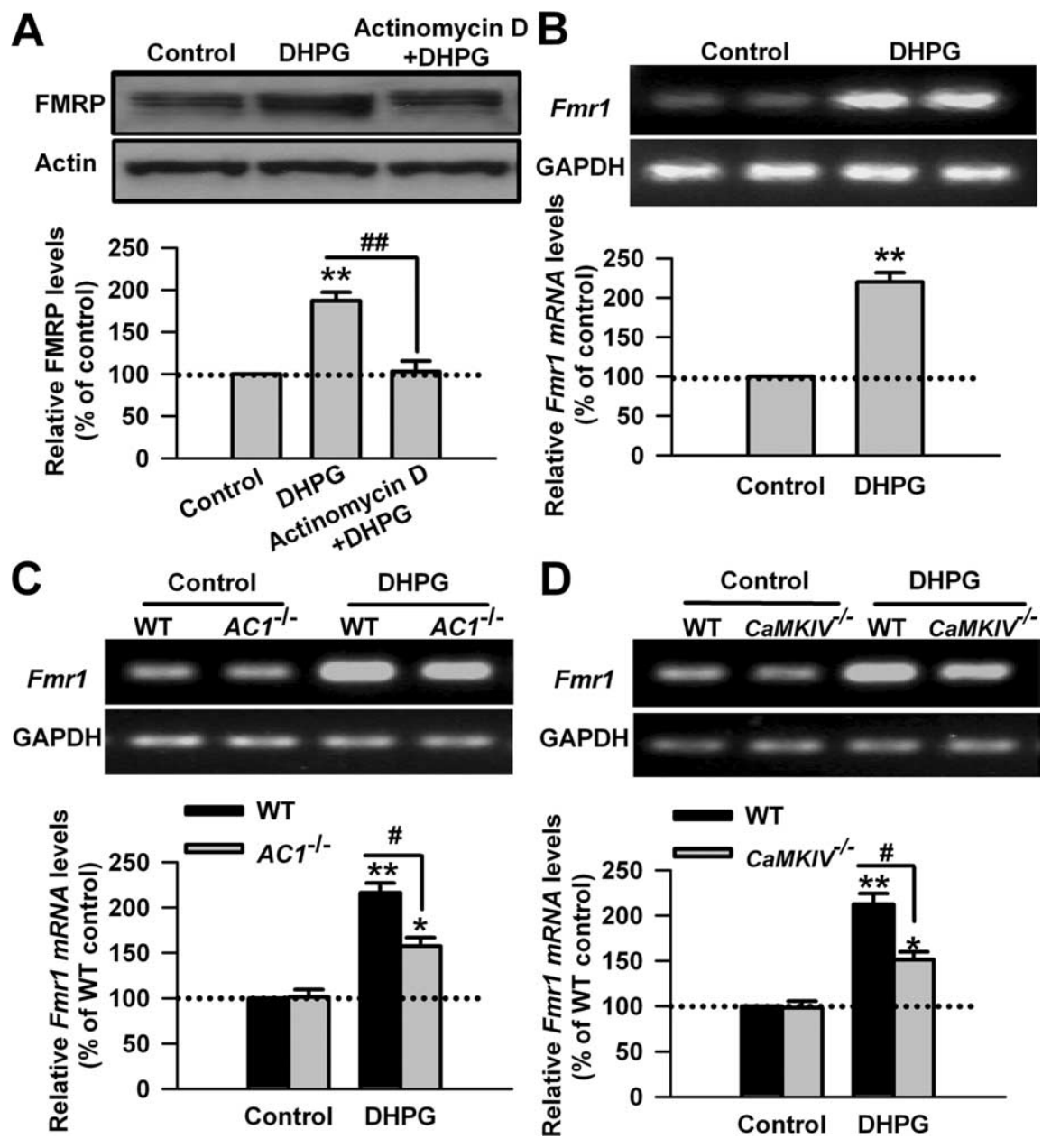

Figure 5. The upregulation of FMRP by group I mGluRs occurs at the transcriptional level. $\boldsymbol{A}$, DNA transcription inhibitor actinomycin D $(40 \mu \mathrm{m})$ abolished the DHPG-induced increase of FMRP in ACC slices, as shown by Western blot. Actinomycin D was applied to slices 20 min before and during DHPG (100 $\mu \mathrm{m})$ treatment for $30 \mathrm{~min}$. B, DHPG (100 $\mu \mathrm{M}, 15 \mathrm{~min})$ treatment increased the levels of $F m r 1 \mathrm{mRNA}$ in ACC slices, as shown by RT-PCR. C, D, The increase of Fmr $1 \mathrm{mRNA}$ was attenuated in ACC slices from AC1 KO (C) or CaMKIV KO (D) mice compared with WT mice, as shown by RT-PCR. The size of PCR products is 141 and $191 \mathrm{bp}$ for Fmr 1 and GAPDH, respectively. Representative gels (top) and quantification data (bottom) of FMRP or Fmr1 mRNA are shown for the corresponding treatments. Data were normalized by WT control values. ${ }^{*} p<0.05$, ${ }^{* *} p<0.01$ compared with control; ${ }^{*} p<0.05$ compared with WT; $n=4$ mice for each group.

cAMP target, followed by the phosphorylation of relevant proteins (Sunahara and Taussig, 2002; Cooper, 2003; Wang and Storm, 2003). To investigate the role of PKA in the regulation of FMRP by group I mGluRs, we next measured the PKA activity in ACC slices. At the basal condition, there was no difference in the PKA activity in ACC slices between WT and $A C 1 \mathrm{KO}$ or $A C 8 \mathrm{KO}$ mice $(p>0.05$ compared with WT mice; $n=4)$ (Fig. $6 A, B)$. DHPG (100 $\mu \mathrm{M}, 15 \mathrm{~min})$ treatment could increase the PKA activity in ACC slices, as measured by the active PKA assay $(p<$ 0.01 compared with DHPG treatment; $n=4$ ) (Fig. 6D). However, the increase of PKA activity induced by DHPG was blocked in ACC slices from AC1 KO mice ( $p<0.01$ compared with WT; $n=4$ ) (Fig. $6 D$ ) but not $A C 8 \mathrm{KO}$ mice ( $p>0.05$ compared with WT mice; $n=4$ ) (Fig. $6 D$ ). These results indicate that PKA is activated by stimulating group I mGluRs in ACC neurons, and $\mathrm{AC} 1$ plays a critical role in this activation.

To further confirm the role of PKA in the regulation of FMRP by group I mGluRs in ACC neurons, we then tested the effect of KT5720, a cell-permeable PKA inhibitor (Moore and Kennedy, 2006; Huang and Kandel, 2007). We found that application of
KT5720 $(10 \mu \mathrm{M}) 15$ min before and during DHPG (100 $\mu \mathrm{M}, 30 \mathrm{~min})$ treatment could partially block the increase of pCREB caused by DHPG $(187 \pm 13$ and $148 \pm$ $10 \%$ of the control levels for DHPG and KT5720 treatment, respectively; $p<0.05$ compared with DHPG treatment; $n=4$ ) (Fig. 6E). Furthermore, application of KT5720 to ACC slices from CaMKIV KO mice could completely block the increase of FMRP caused by DHPG ( $154 \pm 12$ and $103 \pm 9 \%$ of the control levels for DHPG and KT5720 treatment, respectively; $p<$ 0.05 compared with DHPG treatment; $n=$ 4) (Fig. 6F). However, application of KT5720 (10 $\mu \mathrm{M}, 15 \mathrm{~min})$ did not affect the basal levels of FMRP in ACC slices from WT or CaMKIV KO mice ( $p>0.05$ compared with the control; $n=4$ ) (Fig. $6 E, F)$. These data further support the conclusion that the PKA signaling pathway is involved in the regulation of FMRP by group I mGluRs in ACC neurons.

CREB is activated by stimulating group I mGluRs

pCREB binds to the cAMP response element (CRE) site in the gene promoter and activates gene transcription (Bito et al., 1997; Lu et al., 1999; Shaywitz and Greenberg, 1999). Previous studies have shown that activation of group I mGluRs can induce the phosphorylation of CREB and subsequent expression of immediate early gene in cultured striatal neurons (Mao and Wang, 2003; Voulalas et al., 2005; Warwick et al., 2005). It has been reported that the FMR1 gene promoter contains the CRE site (Hwu et al., 1997; Garber et al., 2006), suggesting that CREB may be involved in the regulation of FMR1 gene transcription by group I mGluR activation.

Next, we proceeded to explore whether CREB could be activated by stimulating group I mGluRs in ACC neurons. We checked the phosphorylation of CREB at Ser133 residue, which is phosphorylated by PKA. By immunohistochemistry, we found that pCREB could be expressed at lower level in ACC at the basal condition. The immunoreactivity of pCREB was homogeneously increased by DHPG (100 $\mu \mathrm{M}, 15 \mathrm{~min}$ ) treatment in the cells from layers II-VI of ACC slices (Fig. 7A). The increase of pCREB caused by DHPG in ACC slices was also measured by Western blot $(221 \pm 15 \%$ of the control levels; $p<0.01$ compared with control; $n=6$ ) (Fig. $7 B$ ). The data suggest that the regulation of FMRP by group I mGluRs in ACC neurons likely occurs through CREB activation.

\section{$\mathrm{AC} 1$ and CaMKIV are involved in CREB activation}

$\mathrm{Ca}^{2+} /$ calmodulin-dependent AC isoforms have been shown to be involved in the activation of PKA and the transcription factor CREB (Shaywitz and Greenberg, 1999; Kornhauser et al., 2002; Wei et al., 2002b; Wang et al., 2007). It is possible that AC1 or AC8 may contribute to the activation of CREB caused by stimulating group I mGluRs. We then tested the phosphorylation of CREB induced by DHPG (100 $\mu \mathrm{M}, 15 \mathrm{~min})$ in ACC slices from AC1 KO or AC8 KO 
mice. We found that the phosphorylation of CREB induced by DHPG treatment in ACC slices from $A C 1 \mathrm{KO}$ mice was significantly reduced compared with WT mice $(223 \pm 11$ and $152 \pm 10 \%$ of the WT control levels for $\mathrm{WT}$ and $A C 1 \mathrm{KO}$ mice, respectively; $p<0.05$ compared with WT mice; $n=6$ ) (Fig. 7C). However, there is no difference in the phosphorylation of CREB after DHPG treatment in ACC slices between $A C 8 \mathrm{KO}$ and WT mice $(225 \pm 13$ and $227 \pm 15 \%$ of the WT control levels for WT and AC8 KO mice, respectively; $p>0.05$ compared with WT mice; $n=6$ ) (Fig. 7D). These findings suggest that $\mathrm{ACl}$ plays an isoform-specific role in the phosphorylation of CREB induced by stimulating group I mGluRs in ACC neurons.

To further confirm the role of PKA in the phosphorylation of CREB induced by stimulating group I mGluRs in the ACC neurons, we tested the effect of the PKA inhibitor KT5720. We found that KT5720 $(10 \mu \mathrm{M}, 15 \mathrm{~min})$ did affect the basal levels of pCREB in ACC neurons $(p>0.05$ compared with control; $n=4)$ (Fig. 7E). However, application of KT5720 (10 $\mu \mathrm{M}) 15$ min before and during DHPG (100 $\mu \mathrm{M}, 15 \mathrm{~min})$ treatment could partially block the increase of pCREB caused by DHPG $(216 \pm 12$ and $151 \pm 8 \%$ of the control levels for DHPG and KT5720 treatment, respectively; $p<$ 0.05 compared with DHPG treatment; $n=4$ ) (Fig. $7 E$ ). The data indicate that PKA is required for the activation of CREB by stimulating group I mGluRs in ACC neurons.

CaMKIV activates the transcription factor CREB by phosphorylating CREB on the regulatory Ser133 residue (Bito et al., 1997; Hook and Means, 2001). To investigate whether CaMKIV is involved in the phosphorylation of CREB caused by stimulating group I mGluRs, we then tested the phosphorylation of CREB induced by DHPG $(100 \mu \mathrm{M}, 15 \mathrm{~min})$ in ACC slices from CaMKIV KO mice. We found that the basal levels of pCREB were not changed in ACC slices from CaMKIV KO mice $(p>0.05$ compared with control; $n=4$ ) (Fig. $7 F$ ). However, the phosphorylation of CREB induced by DHPG treatment was partially blocked in ACC slices from CaMKIV KO mice compared with WT mice $(221 \pm 12$ and $149 \pm 9 \%$ of the WT control levels for $\mathrm{WT}$ and CaMKIV KO mice, respectively; $p<0.05$ compared with WT mice; $n=4$ )

(Fig. $7 F$ ). These results indicate that CaMKIV contributes to the phosphorylation of CREB induced by stimulating group I mGluRs in ACC neurons. The application of KT5720 $(10 \mu \mathrm{M}) 15$ min before and during DHPG (100 $\mu \mathrm{M}, 15 \mathrm{~min})$ treatment completely blocked the increase of pCREB caused by DHPG in ACC slices from CaMKIV KO mice (159 \pm
B

\section{cAMP assay}

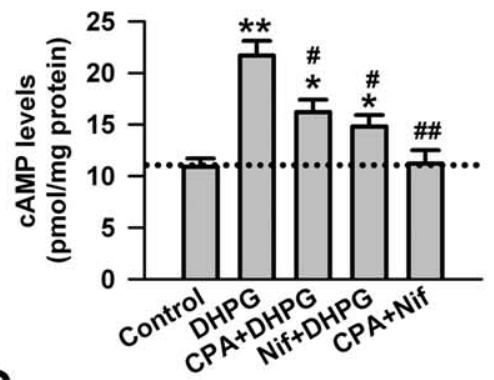

\section{cAMP assay}

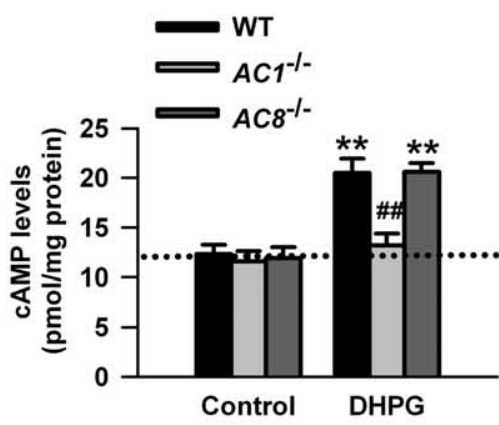

$E$
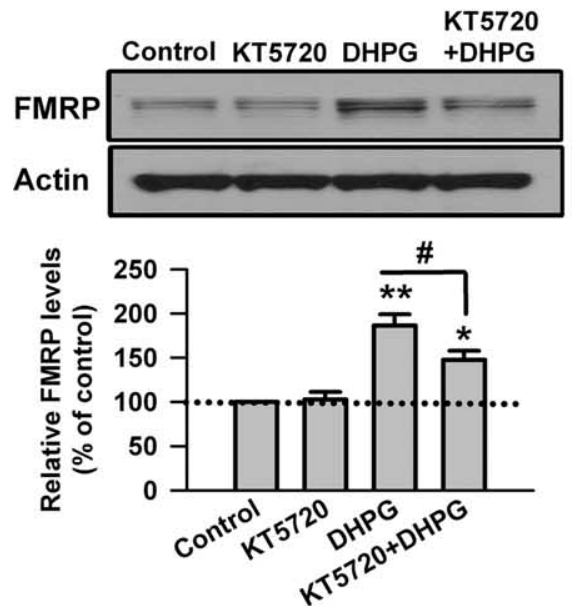

\section{cAMP assay}

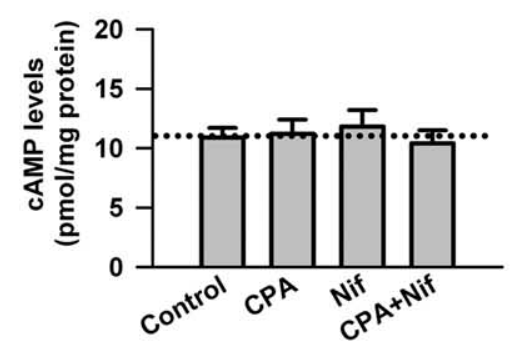

D

PKA assay

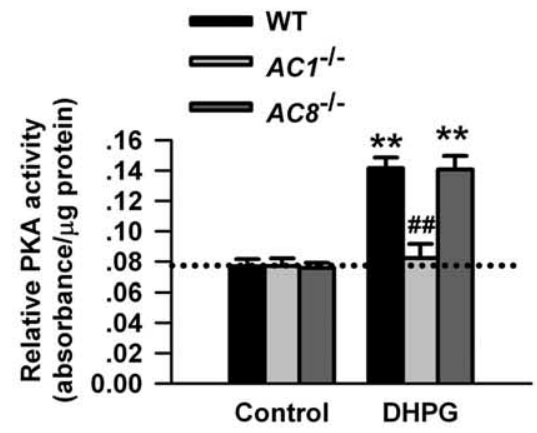

F CaMKIV--mice
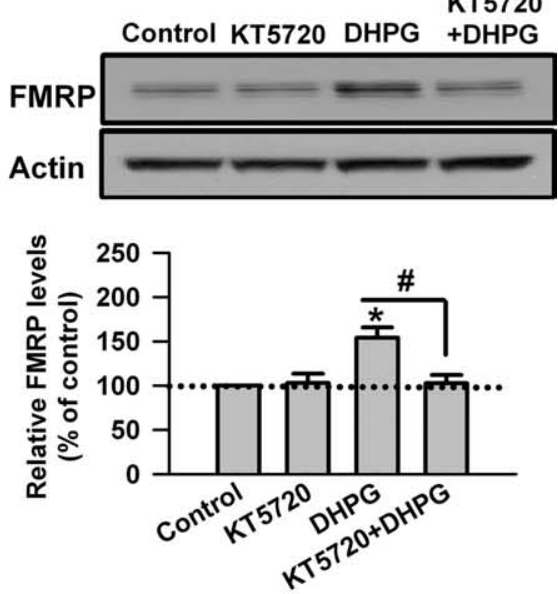

Figure 6. PKA is activated by stimulating group I mGluRs in ACC neurons. $\boldsymbol{A}$, The cAMP levels was increased in ACC slices by DHPG (100 $\mu \mathrm{M}, 15 \mathrm{~min})$ treatment as shown by CAMP assay. Both CPA $(50 \mu \mathrm{M})$ and Nif $(25 \mu \mathrm{M})$ partially blocked the increase of cAMP caused by DHPG. Coapplication of cyclopiazonic acid with nifedipine completely blocked the increase of cAMP caused by DHPG treatment. CPA (50 $\mu \mathrm{m})$ or Nif (25 $\mu \mathrm{m})$ was applied to slices 20 min before and during DHPG treatment. B, Application of cyclopiazonic acid (50 $\mu \mathrm{m}$ ), nifedipine $(25 \mu \mathrm{m})$, or coapplication of cyclopiazonic acid with nifedipine for 30 min did not affect the basal levels of cAMP in ACC slices. $C$, The increase of CAMP was abolished in $A C 1 \mathrm{KO}$ but not in $A C 8 \mathrm{KO}$ mice. $\boldsymbol{D}$, The PKA activity was increased in ACC slices by DHPG $(100 \mu \mathrm{m}, 15 \mathrm{~min})$ treatment, as shown by active PKA assay. The increase of the PKA activity was abolished in $A C 1 \mathrm{KO}$ but not in AC8 KO mice. E, The PKA inhibitor KT5720 (10 $\mu \mathrm{M})$ partially blocked the increase of FMRP caused by DHPG treatment. KT5720 was applied to slices 15 min before and during DHPG treatment. KT5720 (10 $\mu \mathrm{m}, 30 \mathrm{~min})$ did affect the basal levels of FMRP in the ACC neurons. $F$, KT5720 $(10 \mu \mathrm{M})$ abolished the increase of FMRP caused by DHPG treatment in ACC slices from CaMKIV KO mice. KT5720 was applied to slices 15 min before and during DHPG treatment. Representative Western blot (top) and quantification data (bottom) of FMRP are shown for the corresponding treatment in $\boldsymbol{E}$ and $\boldsymbol{F}$. Data were normalized by the control values in $\boldsymbol{E}$ and $\boldsymbol{F}$. ${ }^{*} p<0.05,{ }^{* *} p<0.01$ compared with control in $\boldsymbol{A}-\boldsymbol{F} ;{ }^{\#} p<0.05,{ }^{\# \#} p<0.01$ compared with DHPG treatment in $\boldsymbol{A}, \boldsymbol{E}$, and $\boldsymbol{F} ;{ }^{\# \#} p<0.01$ compared with WT in $\boldsymbol{C}$ and $\boldsymbol{D} ; n=4$ mice for each group.
15 and $104 \pm 11 \%$ from CaMKIV KO mice (159 \pm 15 and $104 \pm 11 \%$ of the control levels for DHPG and KT5720 treatment, respectively; $p<$ 0.05 compared with DHPG treatment; $n=4$ ) (Fig. $7 G$ ). The results further indicate that PKA and CaMKIV are the key molecules that phosphorylate CREB during group I mGluR activation in ACC neurons. 


\section{A pCREB immunostaining} Control
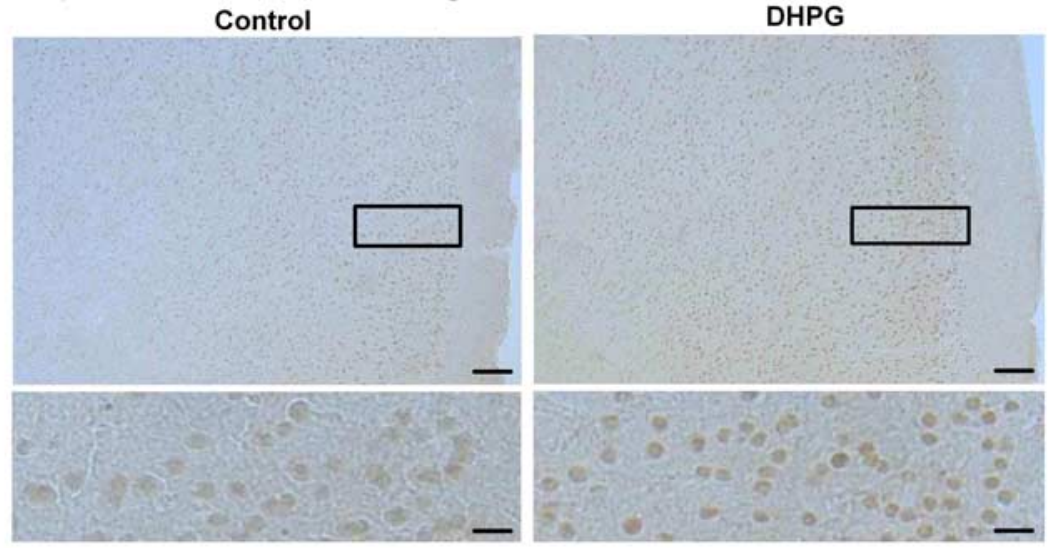

B
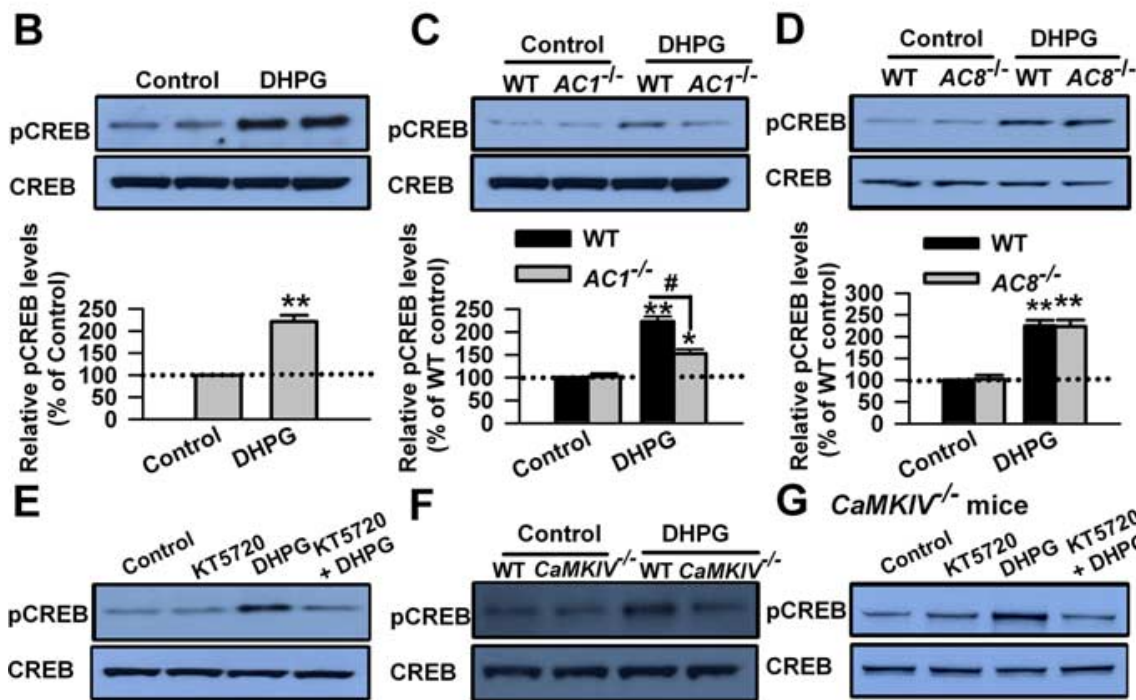

$F$
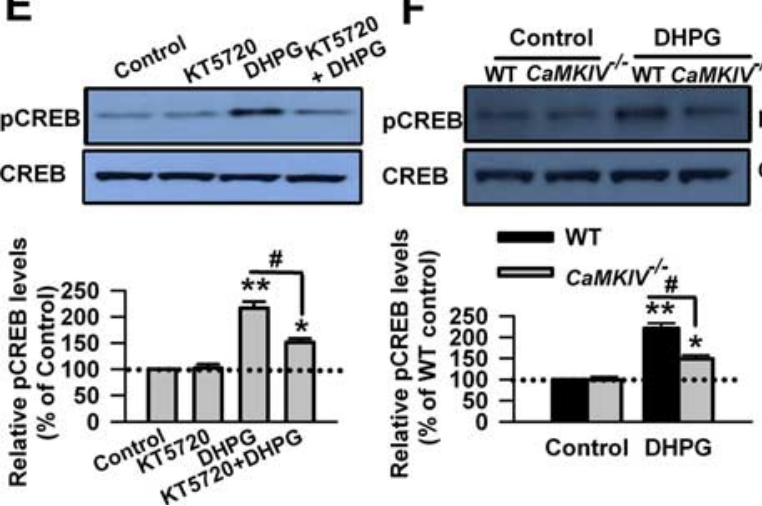

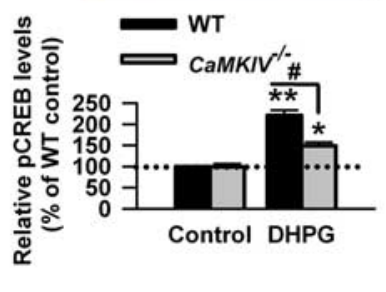

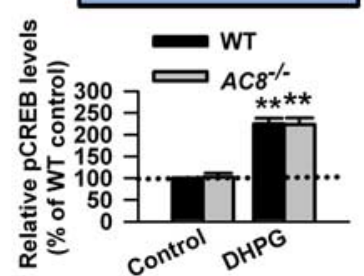

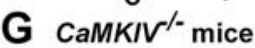
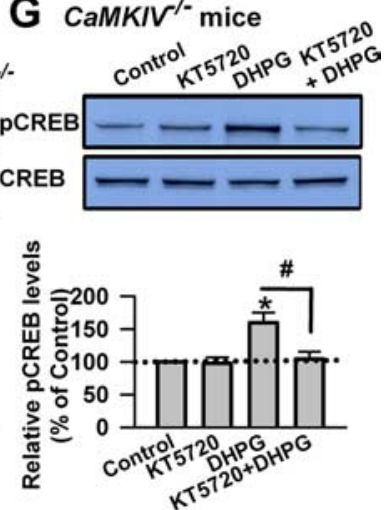

Figure 7. $\mathrm{AC} 1$ and CaMKIV contribute to the phosphorylation of CREB by group I mGluR activation. $\boldsymbol{A}$, Immunohistochemistry of $p C R E B$ in ACC. Compared with the control (left), the increase of the immunoreactivity of $p C R E B$ caused by DHPG (100 $\mu \mathrm{M}, 15 \mathrm{~min}$; right) could be found in neurons from layers II-VI in ACC. A high-magnification image of the selected region showing the staining in layers II-III is provided at the bottom. Scale bars: top, $100 \mu \mathrm{m}$; bottom, $20 \mu \mathrm{m}$. $B$, Activation of group I mGluRs by DHPG induced the phosphorylation of CREB in ACC slices. ACC slices were treated by DHPG $(100 \mu \mathrm{m})$ for $15 \mathrm{~min}$, and the phosphorylation of CREB at Ser133 residue was tested by Western blot. C, The phosphorylation of CREB induced by DHPG (100 $\mu \mathrm{M}, 15 \mathrm{~min})$ treatment was significantly attenuated in ACC slices from $A C 1$ $\mathrm{KO}$ mice compared with WT mice. The basal phosphorylation levels of CREB were not changed in ACC slices from AC1 KO mice. $D$, There is no difference in the phosphorylation levels of CREB after DHPG (100 $\mu \mathrm{m}, 15 \mathrm{~min})$ treatment in ACC slices between $A C 8 \mathrm{~K} 0$ and WT mice. The basal phosphorylation levels of CREB were not changed in ACC slices from AC8 KO mice. $\boldsymbol{E}$, The PKA inhibitor KT5720 $(10 \mu \mathrm{m})$ partially blocked the increase of pCREB caused by DHPG treatment. KT5720 was applied to slices $15 \mathrm{~min}$ before and during DHPG treatment. KT5720 (10 $\mu \mathrm{m}, 15 \mathrm{~min})$ did affect the basal levels of pCREB in ACC neurons. $\boldsymbol{F}$, The phosphorylation of CREB induced by DHPG (100 $\mu \mathrm{M}, 15 \mathrm{~min})$ treatment was significantly attenuated in ACC slices from CaMKIV KO mice compared with WT mice. The basal phosphorylation levels of CREB were not changed in ACC slices from CaMKIV KO mice. G, KT5720 (10 $\mu \mathrm{m})$ abolished the increase of pCREB caused by DHPG treatment in ACC slices from CaMKIV KO mice. KT5720 was applied to slices 15 min before and during DHPG treatment. Representative Western blot (top) and quantification data (bottom) of $p$ CREB levels are shown for corresponding treatments. Data were normalized by the control values in $\boldsymbol{B}, \boldsymbol{E}$, and $\boldsymbol{G}$ and by the WT control values in $\boldsymbol{C}, \boldsymbol{D}$, and $\boldsymbol{F}$; ${ }^{*} p<0.05$, ${ }^{* *} p<0.01$ compared with control from $\boldsymbol{B}-\boldsymbol{G}$; ${ }^{\#} p<0.05$ compared with WT in $\boldsymbol{C}$ and $\boldsymbol{F} ;{ }^{\#} p<0.05$ compared with DHPG treatment in $\boldsymbol{E}$ and $\boldsymbol{G} ; n=3$ mice for each group in experiments in $\boldsymbol{A} ; n=6$ mice for each group in experiments in $\boldsymbol{B} ; n=$ 4 mice for each group in experiments from $\mathbf{C}-\boldsymbol{G}$.

FMRP is downstream of group I mGluRCREB signaling pathway

To further confirm that FMRP is downstream of group I mGluRs, we next characterized the function of group I mGluRs in ACC neurons of Fmr1 KO mice. By calcium imaging, we found that increase of $\mathrm{Ca}^{2+}$ signals caused by DHPG $(100 \mu \mathrm{M})$ perfusion in ACC neurons of Fmrl KO mice was similar to that of WT mice ( $p>$ 0.05 compared with WT; $n=6$ and $n=8$ for WT and Fmr1 KO mice, respectively) (Fig. 8A,B). By electrophysiological recording, we found that there was no difference in DHPG-induced currents in ACC neurons between WT and Fmrl KO mice ( $p>0.05$ compared with WT; $n=11$ and $n=8$ for WT and Fmrl KO mice, respectively) (Fig. $8 C, D$ ). These findings provide the direct evidence that genetic deletion of FMRP does not affect the function of group 1 mGluRs in ACC neurons.

FMRP regulates the translation of specific mRNAs and functions as a dynamic regulator of synaptic plasticity (Bear et al., 2004; Garber et al., 2006; Nosyreva and Huber, 2006). FMRP is likely to be critically involved in the biochemical regulation of translation during mGluR activation (Weiler et al., 1997; Antar et al., 2004; Hou et al., 2006). To rule out the possibility that the changes in CREB might be caused by the upregulated FMRP attributable to group I mGluR activation, we then checked the levels of CREB in ACC slices from Fmr 1 $\mathrm{KO}$ mice. By Western blot, we found that the basal levels of pCREB and CREB were not changed in ACC slices from $F m r 1 \mathrm{KO}$ mice compared with WT mice ( $p>0.05$; $n=6$ ) (Fig. 9A). Similarly, the basal level of CaMKIV was not altered in ACC slices of Fmr1 KO mice ( $p>0.05$ compared with WT; $n=4$ ) (Fig. 9A) In addition, the phosphorylation of CREB induced by DHPG $(100 \mu \mathrm{M})$ treatment in ACC slices from Fmr1 KO mice was not affected compared with WT mice $(223 \pm 16$ and $226 \pm 19 \%$ of the WT control levels for WT and Fmr $1 \mathrm{KO}$ mice, respectively; $p>$ 0.05 compared with WT mice; $n=6$ ) (Fig. 9B). These data indicate that the expression and phosphorylation of CREB is not affected by the lack of FMRP and suggest that FMRP is downstream of the group I mGluR-CREB signaling pathway in ACC neurons.

\section{Discussion}

Our previous studies suggest that FMRP is required for the physiological function of ACC (Zhao et al., 2005a). Previous electrophysiological and behavioral 
A

\section{Control}

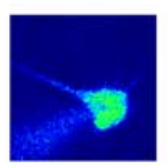

DHPG
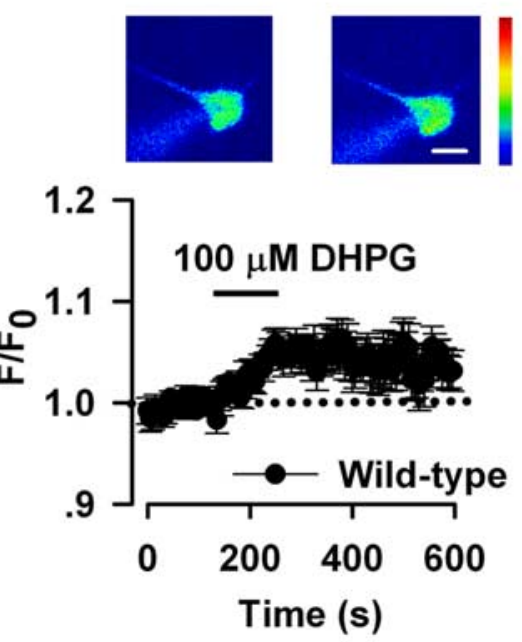

C

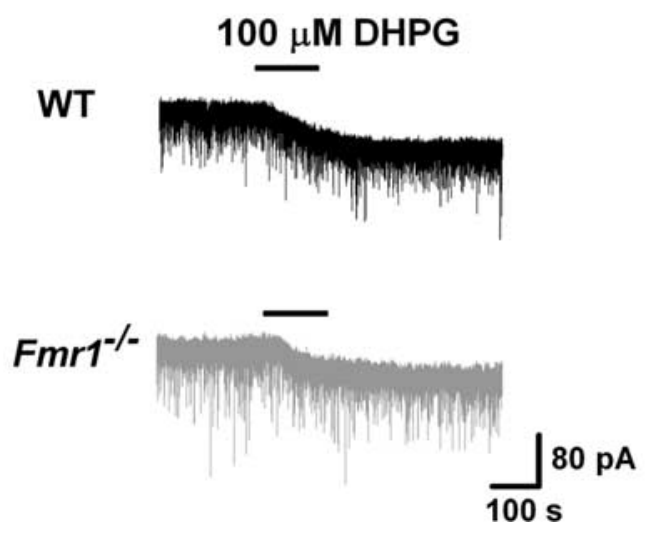

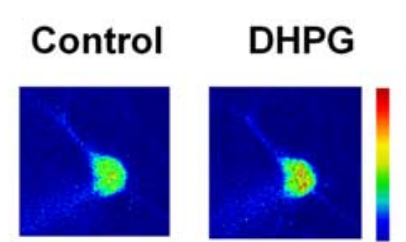

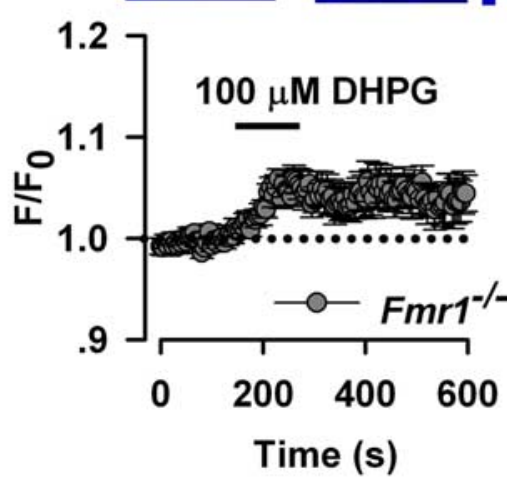

D

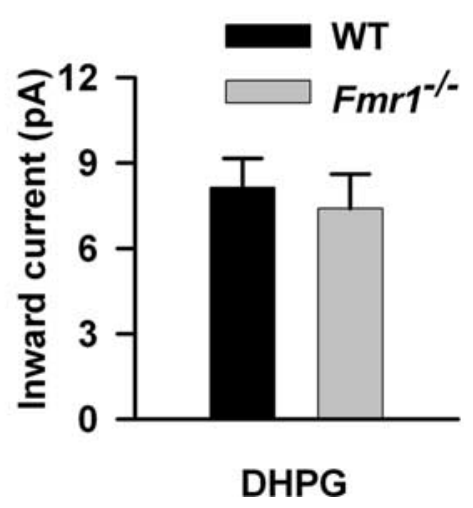

Figure 8. The function of group I mGluRs in ACC neurons is not affected in Fmr $1 \mathrm{KO}$ mice. $\boldsymbol{A}$, Represent images (top) and time plot (bottom) showing that DHPG $(100 \mu \mathrm{m})$ perfusion for 2 min increased the $\mathrm{Ca}^{2+}$ signals in ACC neurons from WT mice $(n=6$ cells). Scale bar, $20 \mu \mathrm{m}$. B , Similar increase of $\mathrm{Ca}^{2+}$ signals were also found in ACC neurons from Fmr $1 \mathrm{KO}$ mice $(n=8$ cells); $p>$ 0.05 compared with that in $\boldsymbol{A}$. C, Typical traces showing the inward current induced by perfusion of DHPG (100 $\mu \mathrm{m})$ for $2 \mathrm{~min}$. $\boldsymbol{D}$, Pooled data showing that there is no difference in DHPG-induced currents between WT ( $n=11$ cells) and Fmr $1^{-/-}(n=8$ cells) mice; $p>0.05$ compared with WT.

studies suggest that the mGluRs in ACC may contribute to the activity-dependent synaptic plasticity and fear memory (Wei et al., 1999; Tang et al., 2005). Here we provide the direct biochemical evidence that activation of group I mGluRs upregulates FMRP in ACC neurons of adult mice. The upregulation of FMRP by group I mGluRs occurs at the transcriptional level. The activation of group I mGluRs induced the phosphorylation of CREB in ACC neurons. AC1 and CaMKIV, but not AC8, contribute to the upregulation of FMRP and the phosphorylation of CREB induced by stimulating group I mGluRs. The activation of group I mGluRs is linked to PKA through $\mathrm{AC} 1$. To our knowledge, this is the first time to show how the expression of FMRP is regulated in ACC neurons. Our results have provided novel evidence that FMRP acts as a key intracellular messenger downstream of $\mathrm{Ca}^{2+} /$ calmodulindependent signaling pathways.
$\mathrm{Ca}^{2+}$ and the expression of FMRP during group I mGluR activation $\mathrm{Ca}^{2+}$ signaling pathway plays a pivotal role in synaptic plasticity (Bito et al., 1997; Shaywitz and Greenberg, 1999; West et al., 2001). $\mathrm{Ca}^{2+}$ is released from $\mathrm{IP}_{3}$-sensitive intracellular stores during group I mGluR activation (Rae et al., 2000; Rae and Irving, 2004; Heinke and Sandkuhler, 2007). In this study, we found that application of sarco/endoplasmic reticulum $\mathrm{Ca}^{2+} /$ ATPase pump inhibitor cyclopiazonic acid before and during group I mGluR activation partially blocked the upregulation of FMRP attributable to group I mGluR activation. Another possible source for intracellular $\mathrm{Ca}^{2+}$ is $\mathrm{Ca}^{2+}$ influx through L-VDCCs. Previous studies have shown that membrane depolarization by DHPG treatment can trigger the opening of L-VDCCs (Bianchi et al., 1999; Mao and Wang, 2003). We found that application of the L-VDCC blocker nifedipine also partially blocked the upregulation of FMRP attributable to group I mGluR activation. When the sarco/endoplasmic reticulum $\mathrm{Ca}^{2+} /$ ATPase pump inhibitor cyclopiazonic acid was coapplied with nifedipine to ACC slices, the upregulation of FMRP was almost completely blocked. It indicates that both $\mathrm{Ca}^{2+}$ release from intracellular stores and $\mathrm{Ca}^{2+}$ influx from L-VDCCs are necessary for the upregulation of FMRP attributable to group I mGluR activation. The role of calcium in the regulation of FMRP by group I mGluRs suggests that the downstream $\mathrm{Ca}^{2+}$-dependent signaling cascades might be involved in this process.

\section{$\mathrm{ACl}, \mathrm{CaMKIV}$, and the regulation of FMRP by group I mGluRs}

$\mathrm{Ca}^{2+} /$ calmodulin-stimulated ACs serve as the transducer of $\mathrm{Ca}^{2+}$ signaling in synaptic plasticity and neuronal survival (Wei et al., 2002b; Liauw et al., 2005; Wang et al., 2007; Zhuo, 2008). AC1 and AC8 are the two major AC isoforms stimulated by $\mathrm{Ca}^{2+} /$ calmodulin in neurons (Cooper et al., 1998; Sunahara and Taussig, 2002; Watts, 2007). In this study, we found that genetic deletion of $A C 1$, but not $A C 8$, could partially block the increase of FMRP induced by group I mGluR activation. In addition, we showed that PKA is required for the upregulation of FMRP by group I mGluRs; AC1, rather than $\mathrm{AC} 8$, is involved in the activation of PKA by group I mGluRs. These results indicate that AC1, but not AC8, is critical for the upregulation of FMRP by stimulating group I mGluRs. The isoform-specific role of $\mathrm{AC} 1$ might be explained by the fact that $\mathrm{AC} 1$ is more sensitive to $\mathrm{Ca}^{2+}$ than AC8, and its calcium sensitivity is approximately fivefold lower than AC1 (Wang and Storm, 2003; Watts, 2007). Thus, in contrast with AC8, AC1 is the major downstream effector for group I mGluRs in ACC neurons. Genetic deletion of $A C 1$ or inhibition of PKA cannot fully block the increase of FMRP induced by group I mGluR activation, 
suggesting that AC1-PKA is not the only signaling pathway involved in this process.

It is well known that CaMKIV transduces $\mathrm{Ca}^{2+}$ signaling and functions as a transcriptional activator in synaptic plasticity (Bito et al., 1997; Hook and Means, 2001; Wei et al., 2002a). It is likely that CaMKIV might be involved in the signaling pathway downstream of group I mGluRs. By using the CaMKIV KO mice, we confirmed that CaMKIV acts downstream of group I mGluRs and contributes to the regulation of FMRP by group I mGluRs in ACC neurons. We also found that inhibiting PKA could completely block the increase of FMRP induced by stimulating group I mGluRs in ACC slice from CaMKIV KO mice. This result further supports the conclusion that both AC1-PKA and CaMKIV are required for the upregulation of FMRP by the activation of group I mGluR in ACC neurons.

\section{CREB and the regulation of FMRP by group I mGluRs}

The CREB is a transcriptional factor that plays an important role in synaptic plasticity (Bito et al., 1997; Kornhauser et al., 2002; Gong et al., 2007). The activity of CREB is regulated by its phosphorylation; $\mathrm{pCREB}$ binds to the CRE site within the gene and activates the gene transcription (Bito et al., 1997; Shaywitz and Greenberg, 1999; Kornhauser et al., 2002). Previous studies have shown that there is the CRE site in FMR1 promoter and implicated CREB in the regulation of the FMR1 gene transcription in neural cells (Hwu et al., 1997; Smith et al., 2006). In this study, we found that the function of group I mGluRs and the phosphorylation of CREB attributable to group I mGluR activation in ACC neurons are not affected in Fmrl KO mice, indicating that FMRP is downstream of the group I mGluR-CREB signaling pathway. This is the first time to provide direct evidence for the functions of mGluRs in ACC neurons of Fmr1 KO mice. Moreover, the group I mGluR-dependent regulation of FMRP in ACC neurons occurs at the transcriptional level, because new Fmr1 mRNA is transcribed, as shown by RT-PCR; the upregulation of FMRP is accompanied by the phosphorylation of CREB (Ser133). These results further support that CREB acts as a transcriptional factor for group I mGluR-dependent regulation of FMRP in the neurons.

There are several signaling pathways that lead to the activation of CREB (Fig. 9C). $\mathrm{Ca}^{2+}$ and cAMP are the principal second messengers that control the phosphorylation of CREB at its regulatory site (Ser133) (Bito et al., 1997; Shaywitz and Greenberg, 1999; Kornhauser et al., 2002). pCREB can be used as a marker for the activation of ACs in the CNS (Wei et al., 2002b; Wang et al., 2007). In this study, we found that pharmacological inhibition of PKA partially blocked the phosphorylation of CREB induced by
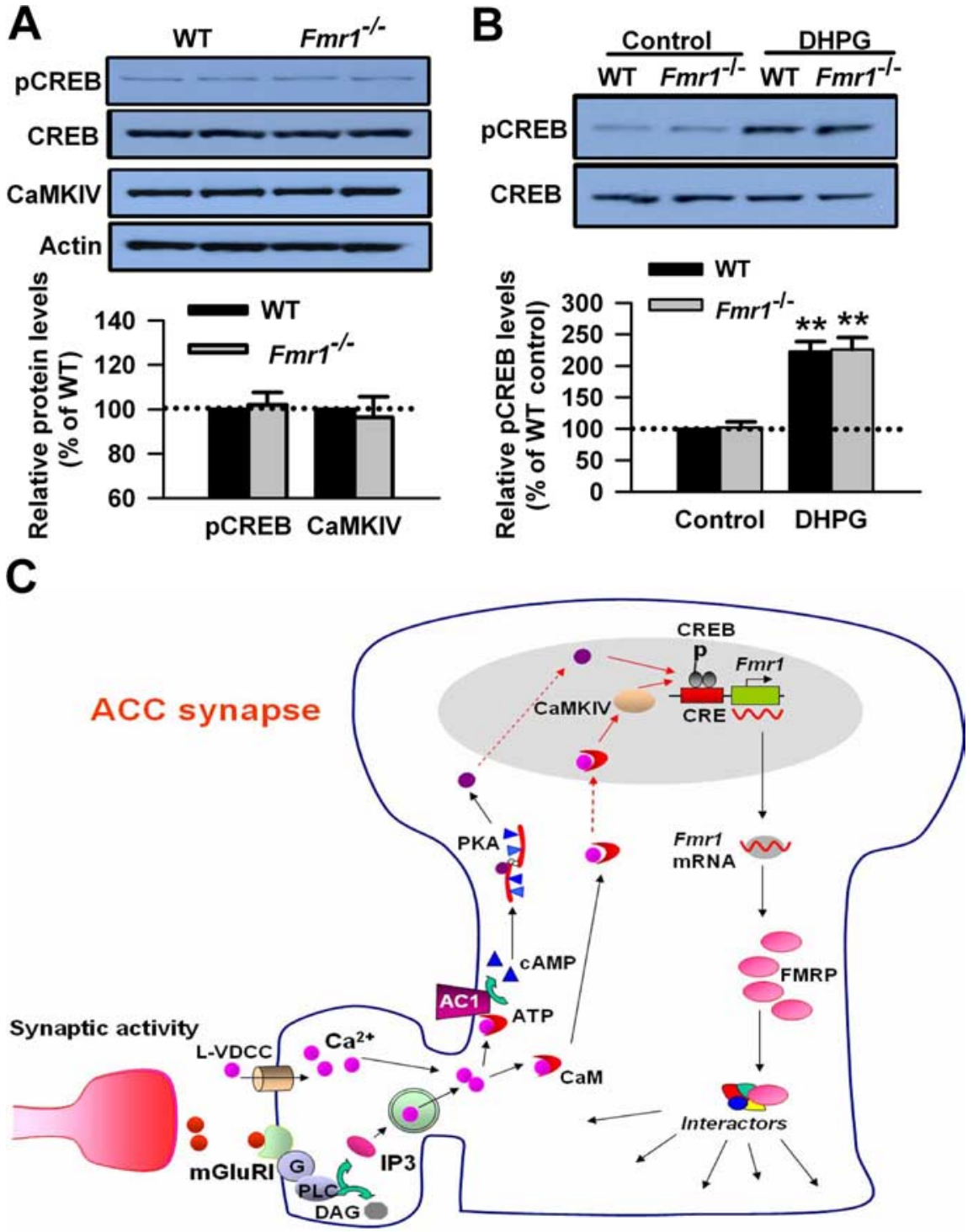

Figure 9. FMRP is downstream of the group I mGluR-CREB pathway in ACC neurons. $A$, There is no difference in basal levels of CREB in ACC between WT and Fmr1 KO mice. The basal levels of CaMKIV were not affected in ACC of Fmr 1 KO mice compared with that of WT mice. $\boldsymbol{B}$, The phosphorylation of CREB induced by DHPG treatment was not affected in Fmr 1 KO mice compared with WT mice. The slices were treated with DHPG $(100 \mu \mathrm{m})$ for $15 \mathrm{~min}$. Representative Western blot (top) and quantification data (bottom) of $p$ CREB levels are shown for corresponding treatments. Data were normalized by WT control values. ${ }^{* *} p<0.01$ compared with control; $n=4$ mice for each group in $\boldsymbol{A} ; n=6$ mice in $\boldsymbol{B}$. $\boldsymbol{C}$, The proposed signaling pathway for the regulation of FMRP by group I mGluRs in ACC neurons. Activation of group I mGluR triggers the $\mathrm{Ca}^{2+}$ release from intracellular calcium stores by $\mathrm{IP}_{3}$ and $\mathrm{Ca}^{2+}$ influx from L-VDCCs through membrane depolarization. Postsynaptic increases in $\mathrm{Ca}^{2+}$ leads to activation of $\mathrm{Ca}^{2+}$ - calmodulin (CaM)-dependent pathways. Among them, $\mathrm{Ca}^{2+}$ and $\mathrm{CaM}$-stimulated $\mathrm{AC} 1$ is activated, and this activation leads to the generation of the key second-messenger CAMP. Subsequently, CAMP activates the PKA. PKA then translocates to the nucleus and phosphorylates CREB. In addition to the CAMP-PKA pathway, rapid CaM translocation into the nucleus activates CaMKIV. CaMKIV then phosphorylates CREB. pCREB initiates the CREB-dependent transcription of Fmr1 gene and upregulates FMRP in the cytoplasm. FMRP may interact with several FRMP interactors and causes changes in neuronal functions in ACC.

DHPG in ACC slices, indicating that the cAMP-PKA signaling pathway in involved in this process. We then characterized the role of $\mathrm{Ca}^{2+} /$ calmodulin-stimulated ACs in the phosphorylation of CREB induced by group I mGluR activation in ACC slices. We found that the phosphorylation of CREB induced by DHPG was attenuated in ACC slices from AC1 KO, but not AC8 KO mice, compared with WT mice. CaMKIV is implicated in various aspects of the neuronal $\mathrm{Ca}^{2+}$ signaling pathways, inducing the phosphorylation of CREB and the gene expression in response to excitatory neurotransmission (Bito et al., 1997; Ho et al., 2000). 
We found that the phosphorylation of CREB induced by DHPG was partially blocked in ACC slices from CaMKIV KO mice. Moreover, pharmacological inhibition of PKA could completely block the increase of pCREB induced by DHPG in ACC of CaMKIV KO mice. Together, these data indicate that $\mathrm{ACl}$ and CaMKIV are critically involved in the activation of CREB induced by stimulating group I mGluRs, $\mathrm{AC} 1$ and CaMKIV contribute to the regulation of FMRP through CREB activation in ACC neurons.

A previous study showed that the DHPG-induced increase of FMRP is protein synthesis dependent and depends on the activation of mGluR5 rather than mGluR1 in hippocampus (Hou et al., 2006). In contrast, we found that the upregulation of FMRP by group I mGluRs occurs at the transcriptional level in cingulate cortex. In addition, the upregulation of FMRP depends on the activation of both mGluR1 and mGluR5 in ACC neurons. The differences between the findings from these two studies may be caused by the differences in the composition of neuronal types between hippocampus and cingulate cortex. Alternatively, the differences might reflect the possible functional diversity of group I mGluRs or FMRP in different brain areas. Future studies are definitely needed to study the mechanisms underlying the differences in the regulation of FMRP by group I mGluRs between hippocampus and cingulate cortex.

In summary, we have demonstrated that the activation of group I mGluRs upregulates FMRP in ACC neurons. $\mathrm{Ca}^{2+}$ is the key messenger for the regulation of FMRP by group I mGluRs; the regulation occurs at the transcriptional level. The activation of CREB is involved in this process. $\mathrm{AC} 1$ and CaMKIV, the major $\mathrm{Ca}^{2+}$ sensors, contribute to the upregulation of FMRP through the activation of CREB (for model, see Fig. 9C). Our study has provided strong evidence for the regulation of FMRP by group I mGluRs in ACC neurons and may help to further elucidate the cellular mechanisms underlying fragile $\mathrm{X}$ syndrome.

\section{References}

Antar LN, Afroz R, Dictenberg JB, Carroll RC, Bassell GJ (2004) Metabotropic glutamate receptor activation regulates fragile $\mathrm{x}$ mental retardation protein and FMR1 mRNA localization differentially in dendrites and at synapses. J Neurosci 24:2648-2655.

Bagni C, Greenough WT (2005) From mRNP trafficking to spine dysmorphogenesis: the roots of fragile X syndrome. Nat Rev Neurosci 6:376-387.

Bear MF, Huber KM, Warren ST (2004) The mGluR theory of fragile X mental retardation. Trends Neurosci 27:370-377.

Belmonte MK, Bourgeron T (2006) Fragile X syndrome and autism at the intersection of genetic and neural networks. Nat Neurosci 9:1221-1225.

Bianchi R, Young SR, Wong RK (1999) Group I mGluR activation causes voltage-dependent and -independent $\mathrm{Ca}^{2+}$ rises in hippocampal pyramidal cells. J Neurophysiol 81:2903-2913.

Bito H, Deisseroth K, Tsien RW (1997) $\mathrm{Ca}^{2+}$-dependent regulation in neuronal gene expression. Curr Opin Neurobiol 7:419-429.

Cartmell J, Schaffhauser H, Wichmann J, Mutel V (1997) mGluR-evoked augmentation of receptor-mediated cyclic AMP formation in neonatal and adult rat striatum. Br J Pharmacol 121:1263-1268.

Cartmell J, Goepfert F, Knoflach F, Pink JR, Bleuel Z, Richards JG, Schaffhauser H, Kemp JA, Wichmann J, Mutel V (1998) Effect of metabotropic glutamate receptor activation on receptor-mediated cyclic AMP responses in primary cultures of rat striatal neurones. Brain Res 791:191-199.

Chavis P, Fagni L, Bockaert J, Lansman JB (1995) Modulation of calcium channels by metabotropic glutamate receptors in cerebellar granule cells. Neuropharmacology 34:929-937.

Chavis P, Fagni L, Lansman JB, Bockaert J (1996) Functional coupling between ryanodine receptors and L-type calcium channels in neurons. Nature 382:719-722.

Cooper DM (2003) Regulation and organization of adenylyl cyclases and cAMP. Biochem J 375:517-529.
Cooper DM, Crossthwaite AJ (2006) Higher-order organization and regulation of adenylyl cyclases. Trends Pharmacol Sci 27:426-431.

Cooper DM, Karpen JW, Fagan KA, Mons NE (1998) $\mathrm{Ca}^{2+}$-sensitive adenylyl cyclases. Adv Second Messenger Phosphoprotein Res 32:23-51.

Coutinho V, Knopfel T (2002) Metabotropic glutamate receptors: electrical and chemical signaling properties. The Neuroscientist 8:551-561.

Feng Y, Zhang F, Lokey LK, Chastain JL, Lakkis L, Eberhart D, Warren ST (1995) Translational suppression by trinucleotide repeat expansion at FMR1. Science 268:731-734.

Fitzjohn SM, Palmer MJ, May JE, Neeson A, Morris SA, Collingridge GL (2001) A characterisation of long-term depression induced by metabotropic glutamate receptor activation in the rat hippocampus in vitro. J Physiol (Lond) 537:421-430.

Frankland PW, O’Brien C, Ohno M, Kirkwood A, Silva AJ (2001) AlphaCaMKII-dependent plasticity in the cortex is required for permanent memory. Nature 411:309-313.

Frankland PW, Bontempi B, Talton LE, Kaczmarek L, Silva AJ (2004) The involvement of the anterior cingulate cortex in remote contextual fear memory. Science 304:881-883.

Garber K, Smith KT, Reines D, Warren ST (2006) Transcription, translation and fragile X syndrome. Curr Opin Genet Dev 16:270-275.

Gong B, Wang H, Gu S, Heximer SP, Zhuo M (2007) Genetic evidence for the requirement of adenylyl cyclase 1 in synaptic scaling of forebrain cortical neurons. Eur J Neurosci 26:275-288.

Greenough WT, Klintsova AY, Irwin SA, Galvez R, Bates KE, Weiler IJ (2001) Synaptic regulation of protein synthesis and the fragile $\mathrm{X}$ protein. Proc Natl Acad Sci USA 98:7101-7106.

Grossman AW, Aldridge GM, Weiler IJ, Greenough WT (2006) Local protein synthesis and spine morphogenesis: fragile $\mathrm{X}$ syndrome and beyond. J Neurosci 26:7151-7155.

Han CJ, O'Tuathaigh CM, van Trigt L, Quinn JJ, Fanselow MS, Mongeau R, Koch C, Anderson DJ (2003) Trace but not delay fear conditioning requires attention and the anterior cingulate cortex. Proc Natl Acad Sci USA 100:13087-13092.

Hayashi ML, Rao BS, Seo JS, Choi HS, Dolan BM, Choi SY, Chattarji S, Tonegawa S (2007) Inhibition of p21-activated kinase rescues symptoms of fragile $\mathrm{X}$ syndrome in mice. Proc Natl Acad Sci USA 104:11489-11494.

Heinke B, Sandkuhler J (2005) Signal transduction pathways of Group I metabotropic glutamate receptor-induced long-term depression at sensory spinal synapses. Pain 118:145-154.

Heinke B, Sandkuhler J (2007) Group I metabotropic glutamate receptorinduced $\mathrm{Ca}^{2+}$-gradients in rat superficial spinal dorsal horn neurons. Neuropharmacology 52:1015-1023.

Ho N, Liauw JA, Blaeser F, Wei F, Hanissian S, Muglia LM, Wozniak DF, Nardi A, Arvin KL, Holtzman DM, Linden DJ, Zhuo M, Muglia LJ, Chatila TA (2000) Impaired synaptic plasticity and cAMP response element-binding protein activation in $\mathrm{Ca}^{2+} /$ calmodulin-dependent protein kinase type IV/Gr-deficient mice. J Neurosci 20:6459-6472.

Hook SS, Means AR (2001) $\mathrm{Ca}^{2+} / \mathrm{CaM}$-dependent kinases: from activation to function. Annu Rev Pharmacol Toxicol 41:471-505.

Hou L, Antion MD, Hu D, Spencer CM, Paylor R, Klann E (2006) Dynamic translational and proteasomal regulation of fragile $\mathrm{X}$ mental retardation protein controls mGluR-dependent long-term depression. Neuron 51:441-454.

Huang YY, Kandel ER (2007) 5-Hydroxytryptamine induces a protein kinase $\mathrm{A} /$ mitogen-activated protein kinase-mediated and macromolecular synthesis-dependent late phase of long-term potentiation in the amygdala. J Neurosci 27:3111-3119.

Huber K (2007) Fragile X syndrome: molecular mechanisms of cognitive dysfunction. Am J Psychiatry 164:556.

Huber KM, Gallagher SM, Warren ST, Bear MF (2002) Altered synaptic plasticity in a mouse model of fragile X mental retardation. Proc Natl Acad Sci USA 99:7746-7750.

Hwu WL, Wang TR, Lee YM (1997) FMR1 enhancer is regulated by cAMP through a cAMP-responsive element. DNA Cell Biol 16:449-453.

Jin P, Warren ST (2003) New insights into fragile X syndrome: from molecules to neurobehaviors. Trends Biochem Sci 28:152-158.

Kornhauser JM, Cowan CW, Shaywitz AJ, Dolmetsch RE, Griffith EC, Hu LS, Haddad C, Xia Z, Greenberg ME (2002) CREB transcriptional activity in neurons is regulated by multiple, calcium-specific phosphorylation events. Neuron 34:221-233. 
Liauw J, Wu LJ, Zhuo M (2005) Calcium-stimulated adenylyl cyclases required for long-term potentiation in the anterior cingulate cortex. J Neurophysiol 94:878-882.

Lu YF, Kandel ER, Hawkins RD (1999) Nitric oxide signaling contributes to late-phase LTP and CREB phosphorylation in the hippocampus. J Neurosci 19:10250-10261.

Mao L, Wang JQ (2003) Group I metabotropic glutamate receptormediated calcium signalling and immediate early gene expression in cultured rat striatal neurons. Eur J Neurosci 17:741-750.

Means AR, Cruzalegui F, LeMagueresse B, Needleman DS, Slaughter GR, Ono T (1991) A novel $\mathrm{Ca}^{2+} /$ calmodulin-dependent protein kinase and a male germ cell-specific calmodulin-binding protein are derived from the same gene. Mol Cell Biol 11:3960-3971.

Moore SW, Kennedy TE (2006) Protein kinase A regulates the sensitivity of spinal commissural axon turning to netrin-1 but does not switch between chemoattraction and chemorepulsion. J Neurosci 26:2419-2423.

Moult PR, Gladding CM, Sanderson TM, Fitzjohn SM, Bashir ZI, Molnar E, Collingridge GL (2006) Tyrosine phosphatases regulate AMPA receptor trafficking during metabotropic glutamate receptor-mediated long-term depression. J Neurosci 26:2544-2554.

Nakamoto M, Nalavadi V, Epstein MP, Narayanan U, Bassell GJ, Warren ST (2007) Fragile X mental retardation protein deficiency leads to excessive mGluR5-dependent internalization of AMPA receptors. Proc Natl Acad Sci USA 104:15537-15542.

Nosyreva ED, Huber KM (2006) Metabotropic receptor-dependent longterm depression persists in the absence of protein synthesis in the mouse model of fragile X syndrome. J Neurophysiol 95:3291-3295.

Rae MG, Irving AJ (2004) Both mGluR1 and mGluR5 mediate $\mathrm{Ca}^{2+}$ release and inward currents in hippocampal CA1 pyramidal neurons. Neuropharmacology 46:1057-1069.

Rae MG, Martin DJ, Collingridge GL, Irving AJ (2000) Role of $\mathrm{Ca}^{2+}$ stores in metabotropic L-glutamate receptor-mediated supralinear $\mathrm{Ca}^{2+}$ signaling in rat hippocampal neurons. J Neurosci 20:8628-8636.

Scerif G, Cornish K, Wilding J, Driver J, Karmiloff-Smith A (2007) Delineation of early attentional control difficulties in fragile X syndrome: focus on neurocomputational changes. Neuropsychologia 45:1889-1898.

Schaffhauser H, de Barry J, Muller H, Heitz MP, Gombos G, Mutel V (1997) Involvement of a cyclic-AMP pathway in Group I metabotropic glutamate receptor responses in neonatal rat cortex. Eur J Pharmacol 334:289-297.

Shaywitz AJ, Greenberg ME (1999) CREB: a stimulus-induced transcription factor activated by a diverse array of extracellular signals. Annu Rev Biochem 68:821-861.

Smith KT, Nicholls RD, Reines D (2006) The gene encoding the fragile X RNA-binding protein is controlled by nuclear respiratory factor 2 and the CREB family of transcription factors. Nucleic Acids Res 34:1205-1215.

Sun Z, Means RL, LeMagueresse B, Means AR (1995) Organization and analysis of the complete rat calmodulin-dependent protein kinase IV gene. J Biol Chem 270:29507-29514.

Sunahara RK, Taussig R (2002) Isoforms of mammalian adenylyl cyclase: multiplicities of signaling. Mol Interv 2:168-184.

Tang J, Ko S, Ding HK, Qiu CS, Calejesan AA, Zhuo M (2005) Pavlovian fear memory induced by activation in the anterior cingulate cortex. Mol Pain 1:6.

Thuault SJ, Davies CH, Randall AD, Collingridge GL (2002) Group I mGluRs modulate the pattern of non-synaptic epileptiform activity in the hippocampus. Neuropharmacology 43:141-146.
Todd PK, Mack KJ, Malter JS (2003) The fragile X mental retardation protein is required for type-I metabotropic glutamate receptor-dependent translation of PSD-95. Proc Natl Acad Sci USA 100:14374-14378.

Voulalas PJ, Holtzclaw L, Wolstenholme J, Russell JT, Hyman SE (2005) Metabotropic glutamate receptors and dopamine receptors cooperate to enhance extracellular signal-regulated kinase phosphorylation in striatal neurons. J Neurosci 25:3763-3773.

Wang H, Storm DR (2003) Calmodulin-regulated adenylyl cyclases: crosstalk and plasticity in the central nervous system. Mol Pharmacol 63:463-468.

Wang H, Gong B, Vadakkan KI, Toyoda H, Kaang BK, Zhuo M (2007) Genetic evidence for adenylyl cyclase 1 as a target for preventing neuronal excitotoxicity mediated by $\mathrm{N}$-methyl-D-aspartate receptors. J Biol Chem 282:1507-1517.

Warwick HK, Nahorski SR, Challiss RA (2005) Group I metabotropic glutamate receptors, mGlula and mGlu5a, couple to cyclic AMP response element binding protein (CREB) through a common $\mathrm{Ca}^{2+}$ - and protein kinase C-dependent pathway. J Neurochem 93:232-245.

Watts VJ (2007) Adenylyl cyclase isoforms as novel therapeutic targets: an exciting example of excitotoxicity neuroprotection. Mol Interv 7:70-73.

Wei F, Li P, Zhuo M (1999) Loss of synaptic depression in mammalian anterior cingulate cortex after amputation. J Neurosci 19:9346-9354.

Wei F, Qiu CS, Liauw J, Robinson DA, Ho N, Chatila T, Zhuo M (2002a) Calcium calmodulin-dependent protein kinase IV is required for fear memory. Nat Neurosci 5:573-579.

Wei F, Qiu CS, Kim SJ, Muglia L, Maas JW, Pineda VV, Xu HM, Chen ZF, Storm DR, Muglia LJ, Zhuo M (2002b) Genetic elimination of behavioral sensitization in mice lacking calmodulin-stimulated adenylyl cyclases. Neuron 36:713-726.

Wei F, Vadakkan KI, Toyoda H, Wu LJ, Zhao MG, Xu H, Shum FW, Jia YH, Zhuo M (2006) Calcium calmodulin-stimulated adenylyl cyclases contribute to activation of extracellular signal-regulated kinase in spinal dorsal horn neurons in adult rats and mice. J Neurosci 26:851-861.

Weiler IJ, Irwin SA, Klintsova AY, Spencer CM, Brazelton AD, Miyashiro K, Comery TA, Patel B, Eberwine J, Greenough WT (1997) Fragile X mental retardation protein is translated near synapses in response to neurotransmitter activation. Proc Natl Acad Sci USA 94:5395-5400.

Weiler IJ, Spangler CC, Klintsova AY, Grossman AW, Kim SH, BertainaAnglade V, Khaliq H, de Vries FE, Lambers FA, Hatia F, Base CK, Greenough WT (2004) Fragile X mental retardation protein is necessary for neurotransmitter-activated protein translation at synapses. Proc Natl Acad Sci USA 101:17504-17509.

West AE, Chen WG, Dalva MB, Dolmetsch RE, Kornhauser JM, Shaywitz AJ, Takasu MA, Tao X, Greenberg ME (2001) Calcium regulation of neuronal gene expression. Proc Natl Acad Sci USA 98:11024-11031.

Zhao MG, Toyoda H, Ko SW, Ding HK, Wu LJ, Zhuo M (2005a) Deficits in trace fear memory and long-term potentiation in a mouse model for fragile X syndrome. J Neurosci 25:7385-7392.

Zhao MG, Toyoda H, Lee YS, Wu LJ, Ko SW, Zhang XH, Jia Y, Shum F, Xu H, Li BM, Kaang BK, Zhuo M (2005b) Roles of NMDA NR2B subtype receptor in prefrontal long-term potentiation and contextual fear memory. Neuron 47:859-872.

Zhuo M (2006) Molecular mechanisms of pain in the anterior cingulate cortex. J Neurosci Res 84:927-933.

Zhuo M (2008) Cortical excitation and chronic pain. Trends Neurosci 31: 199-207. 